Original article

\title{
Comparative phylogeography of the western Indian Ocean reef fauna
}

\author{
Philippe Borsa ${ }^{a}$,, Jean-Dominique Durand ${ }^{\mathrm{b}}$, Wei-Jen Chen ${ }^{\mathrm{c}}$, Nicolas Hubert ${ }^{\mathrm{d}}$, \\ Delphine Muths ${ }^{\mathrm{e}, \mathrm{f}}$, Gérard Mou-Tham ${ }^{\mathrm{a}}$, Michel Kulbicki ${ }^{\mathrm{a}}$ \\ a Institut de Recherche pour le Développement (IRD), UMR EMTROPI and LabEx “Corail”, Nouméa, New Caledonia, France \\ ${ }^{\mathrm{b}}$ IRD, UMR MARBEC, Montpellier, France \\ ${ }^{\mathrm{c}}$ Institute of Oceanography, National Taiwan University, Taipei, Taiwan, ROC \\ d IRD, UMR ISEM, Montpellier, France \\ e IFREMER, Délégation de l'océan Indien, Le Port, La Réunion, France \\ ${ }^{\mathrm{f}}$ Université Européenne de Bretagne, Rennes, France
}

\section{A R T I C L E I N F O}

\section{Article history:}

Received 10 February 2015

Received in revised form

21 October 2015

Accepted 21 October 2015

Available online 31 October 2015

\section{Keywords:}

Indo-West Pacific

Biogeographic province

Endemism

Reef fish

Mitochondrial DNA

Parsimony network

\begin{abstract}
A B S T R A C T
Assessing patterns of connectivity at the community and population levels is relevant to marine resource management and conservation. The present study reviews this issue with a focus on the western Indian Ocean (WIO) biogeographic province. This part of the Indian Ocean holds more species than expected from current models of global reef fish species richness. In this study, checklists of reef fish species were examined to determine levels of endemism in each of 10 biogeographic provinces of the Indian Ocean. Results showed that the number of endemic species was higher in the WIO than in any other region of the Indian Ocean. Endemic species from the WIO on the average had a larger body size than elsewhere in the tropical Indian Ocean. This suggests an effect of peripheral speciation, as previously documented in the Hawaiian reef fish fauna, relative to other sites in the tropical western Pacific. To explore evolutionary dynamics of species across biogeographic provinces and infer mechanisms of speciation, we present and compare the results of phylogeographic surveys based on compilations of published and unpublished mitochondrial DNA sequences for 19 Indo-Pacific reef-associated fishes (rainbow grouper Cephalopholis argus, scrawled butterflyfish Chaetodon meyeri, bluespot mullet Crenimugil sp. A, humbug damselfish Dascyllus abudafur/Dascyllus aruanus, areolate grouper Epinephelus areolatus, blacktip grouper Epinephelus fasciatus, honeycomb grouper Epinephelus merra, bluespotted cornetfish Fistularia commersonii, cleaner wrasse Labroides sp. 1, longface emperor Lethrinus sp. A, bluestripe snapper Lutjanus kasmira, unicornfishes Naso brevirosris, Naso unicornis and Naso vlamingii, blue-spotted maskray Neotrygon kuhlii, largescale mullet Planiliza macrolepis, common parrotfish Scarus psicattus, crescent grunter Terapon jarbua, whitetip reef shark Triaenodon obesus) and three coastal Indo-West Pacific invertebrates (blue seastar Linckia laevigata, spiny lobster Panulirus homarus, small giant clam Tridacna maxima). Heterogeneous and often unbalanced sampling design, paucity of data in a number of cases, and among-species discrepancy in phylogeographic structure precluded any generalization regarding phylogeographic patterns. Nevertheless, the WIO might have been a source of haplotypes in some cases and it also harboured an endemic clade in at least one case. The present survey also highlighted likely cryptic species. This may eventually affect the accuracy of the current checklists of species, which form the basis of some of the recent advances in Indo-West Pacific marine ecology and biogeography.
\end{abstract}

๑ 2015 Elsevier Masson SAS. All rights reserved.
* Corresponding author. Present address: IRD-UMR 250 EMTROPI and LabEx “Corail”, c/o Universitas Udayana, Jl Raya Sesetan Gang Markisa no. 6, 80322 Denpasar, Indonesia.

E-mail addresses: philippe.borsa@ird.fr (P. Borsa), jean-dominique.durand@ird.fr (J.-D. Durand), wjchen.actinops@gmail.com (W.-J. Chen), nicolas.hubert@ird.fr (N. Hubert), muthsdelphine@yahoo.fr (D. Muths), gerard.mou-tham@ird.fr (G. Mou-Tham), michel.kulbicki@ird.fr (M. Kulbicki).

\section{Introduction}

\subsection{Background}

Marine biologists define biogeographic provinces as regions of the ocean characterized by the presence of distinct communities that are thought to have some cohesion at the evolutionary 
timescale and found to be distinct from adjacent provinces (Spalding et al., 2007; Briggs and Bowen, 2012, and references therein). Thus-called marine biogeographic provinces generally harbour a proportion of endemic species. The extent of biogeographic provinces generally coincides with geologic and/or oceanographic boundaries (Spalding et al., 2007; and references therein; Briggs and Bowen, 2012; Obura, 2012; Veron et al., 2015). Quantitative delineation of biogeographic provinces based on 169 reef fish checklists from across all tropical oceans (Kulbicki et al., 2013a) showed less clear-cut province boundaries, than those described in the above surveys. The delimitation of biogeographic provinces is viewed as important to help establish patterns of connectivity at the community and the population levels, which in turn has relevance in resource management and conservation (Spalding et al., 2007; Obura, 2012; Kulbicki et al., 2013a; Veron et al., 2015).

Ocean currents transport larvae of sedentary marine species, allowing the connection of geographically-distant habitats suitable for adults. Larval transportation also enables sedentary marine species to colonize new habitats (e.g., recent volcanic islands), and to recolonize habitats where the species have been extirpated. Although the direction and intensity of currents may determine levels of contemporary gene flow, a species' geographic structure over evolutionary time is more likely to be influenced by geographic distance between suitable habitats (Crandall et al., 2014). Albeit not a primary determinant of distribution range size, variability in pelagic larval duration may partly contribute to differences in the distribution of reef fish species in the Indo-Pacific, as species with longer larval duration have a greater chance to disperse over habitats unsuitable to adults than those with shorter pelagic larval duration (Scheltema, 1968; Woodland, 1990; Lester et al., 2007; Treml et al., 2012; Luiz et al., 2013). Adult body size is another factor affecting a species' distribution range (Luiz et al., 2013). Larger adults have higher reproductive output and higherquality offspring (Beldade et al., 2012; Hixon et al., 2014), which enhances the probability of achieving long-distance dispersal. At the intraspecific level, higher larval survival rate potentially translates into higher dispersal ability which in turn translates into potential for higher gene flow between populations. Population genetic differentiation decreases with pelagic larval duration in the tropical Indo-West Pacific fish family Siganidae (Lemer et al., 2007), where geographic range size also increases with pelagic larval duration (Woodland, 1990). Tropical Pacific fishes from families Chaetodontidae, Labridae and Pomacentridae show a similar correlation (Lester and Ruttenberg, 2005; Lester et al., 2007). Selkoe and Toonen (2011) found that pelagic larval duration and genetic differentiation estimates, i.e. S. Wright's Fst and the slope of the isolation-by-distance correlation (Rousset, 1997), typically reflect scales of dispersal if the sampling design is adequate. Gene flow counteracts genetic differentiation by natural selection and genetic drift (Slatkin, 1985), thus hampering adaptation to local conditions.

\subsection{The western Indian Ocean (WIO) province}

The present study focuses on the western Indian Ocean (WIO) province, the westernmost of the tropical Indo-West Pacific domain. The WIO province is defined here as the oceanic region bounded by the eastern coast of Africa from Somalia to Mozambique and extending to the East so as to include the Seychelles and Mascarene archipelagoes. This approximately coincides with Obura's (2012) and Spalding et al.'s (2007) definitions of the Western Indian Ocean province. Briggs and Bowen (2012) did not mention the WIO as a particular biogeographic province in terms of endemism or as a diversity hotspot.

The reef fish fauna of the WIO has attracted increased interest from the scientific community. Smith and Heemstra (1986) described a large proportion of the species occurring in South Africa and adjacent waters (Mozambique, Madagascar). Subsequently, a number of country-based checklists have been proposed in this region (e.g. Iles Eparses, the Comores archipelago, Seychelles, Mascarene Islands). These species checklists were used to delineate biogeographic regions (Kulbicki et al., 2013a), and to relate species richness to a number of large-scale environmental factors, including sea-surface temperature, island size and its degree of isolation, distance from the Coral Triangle, and reef area (Parravicini et al., 2013). These studies, along with previous work on reef fish macro-ecology (Santini and Winterbottom, 2002; Bellwood et al., 2012; Kulbicki et al., 2013b; Mouillot et al., 2013), suggest that the WIO has some specific characteristics. In particular, this part of the Indian Ocean holds more species than expected from modelling based on geomorphologic, biogeographic and environmental explanatory variables (Parravicini et al., 2013; Pellissier et al., 2014). This leads us to hypothesize that the WIO represents either a species sink, a center of origin, or a zone of overlap. Possible routes of migration for reef fishes include along the eastern African coast, from the Maldives-Chagos archipelagoes towards the Seychelles, or from temperate southern Africa towards the North-East. Obura (2012) (p. 1) posits that diversity patterns in WIO corals are consistent with the oceanography of the western Indian Ocean, "reflecting inflow of the South Equatorial Current, maintenance of high diversity in the northern Mozambique Channel, and export from this central region to the north and south, and to the Seychelles and Mascarene islands." This amounts to suggesting that the WIO may harbour specific communities that both receive and export species.

\subsection{Comparative phylogeography as an approach to test biogeographic hypotheses}

Community assembly, the sum of the processes leading to the aggregation of species in ecological communities (Emerson and Gillespie, 2008), results from intricate interactions at the regional and local scales (Ricklefs, 1987; Leibold et al., 2004, 2010). Community assembly is affected by the dynamics of diversification, which drives the biodiversity build-up in a regional pool, and by the ecological dynamics within communities, which limits the number of species that coexist (Hubert et al., 2015). Historical biogeography has traditionally focused on the contribution of geological and paleoecological landscape histories on species diversification at the regional scale (Nelson and Platnick, 1981; Myers and Giller, 1988; Ricklefs and Schluter, 1993). For this, the distributions of species have been analysed to detect coinciding geographical boundaries, which in turn have been linked to known past events (Cracraft and Prum, 1988; Morrone, 1994; Morrone and Escalante, 2002). The introduction of genetic markers into historical biogeography has led to the development of comparative phylogeography, which aims at uncovering shared patterns in the distribution of intraspecific genetic diversity (Avise, 2000). Phylogeography offers the tools and concepts to study the historical processes that may be responsible for the contemporary geographic distributions of gene genealogies. Thus, phylogeography addresses some of the conservation issues that are at the core of modern marine biogeography. This approach has proven to be informative in exploring evolutionary dynamics of species across biogeographical boundaries and in revealing the temporal dynamics underpinning the coincidence of species distributions (Bermingham and Moritz, 1998; Hubert et al., 2007; Lee and Johnson, 2009). Phylogeographic subdivisions generally corroborate biogeographic provinces based on species lists, with a notable exception at the Indian-Pacific boundary (Briggs and Bowen, 2012). Studying phylogeographic structure (i.e., generally at the intraspecific level) allows one to test 
hypotheses on geographic connectivity inferred from species endemicity and species richness data (e.g., Obura, 2012; Kulbicki et al., 2013a).

\subsection{Objectives}

The first objective of this study is to determine whether the reef fish assemblages found in the WIO hold specific properties by (1) comparing species richness in the WIO to other provinces in the Indian Ocean, and (2) examining if the general structure of the WIO's reef fish assemblages is different from adjacent regions. Subsequently, one may hypothesize that the WIO is a species sink, or source, or zone of overlap, which may have important consequences in conservation.

Then, we review the phylogeography of coral reef species with wide Indo-West Pacific distribution to: (i) detect possible multiplespecies patterns of differentiation for WIO populations; (ii) test the biogeographic hypotheses derived from data on reef fish assemblages. Our emphasis is on coral reef fishes, but comparative information on coral reef invertebrates is also included.

\section{Materials and Methods}

\subsection{Partitioning the Indian Ocean into biogeographic provinces}

Spalding et al. (2007) defined biogeographic regions or provinces based on expert advice and estimated that the resulting classification should apply to a large set of marine flora and fauna. Basing their work on coral species lists, Veron et al. (2015) did a cluster analysis which resulted in the eastern African coast, Madagascar, the Mascarene Islands, the Maldives, and Chagos being grouped together. However, the basic biogeographical units they used were derived from Spalding et al.'s (2007) provinces. Kulbicki et al. (2013a) distinguished biogeographical regions for reef fishes using a dissimilarity matrix to build clusters. These authors found that beyond large biogeographical units, the classification of reef fish into small biogeographic units was unstable. Nevertheless, their study showed that the eastern African reef fish fauna was distinct from that of Madagascar and the Mascarene Islands.

In the present work, provinces in the Indian Ocean were primarily defined according to Kulbicki et al. (2013a). For Australia, we chose the partition proposed by the Atlas of Living Australia (http:// regions.ala.org.au/\#rt=imcras). The Andaman-Nicobar archipelago, the Cocos (Keeling) islands and Christmas Island were set apart as this group of islands has a depauperate fauna when compared to the nearby coastal areas of Sumatra and peninsular Malaysia. They are also thought to lie at the boundary between Indian and Pacific ocean faunas as they boast a number of Indian-Pacific geminate species pairs (Hobbs et al., 2009, 2014), a peculiarity that has not yet been documented for the coastal areas of Sumatra and peninsular Malaysia. We applied Ward's algorithm of aggregation (Legendre and Legendre, 2012) on reef fish checklists to help confirm biogeographical units defined from the literature (see above). Depending on the distance metric (Supplementary material, Fig. S1), Madagascar grouped either with eastern Africa (from tropical South Africa to Somalia), or with the Seychelles and the Mascarene Islands. Similarly, the Maldives and Chagos clustered together but depending on the distance metric would do so either with India, Sri Lanka and Lakshadweep, or with the Seychelles, Mascarene Islands, and other localities from eastern Africa (Supplementary material, Fig. S1). Therefore, we deemed it difficult to assign checklists to a given biogeographical region or province. The final classification proposed here (Fig. 1) combined the views of Spalding et al. (2007), Kulbicki et al. (2013a), Veron et al. (2015), and the results presented in Supplementary material, Fig. S1. This is intended as a consensus, reached with a certain part of subjectivity. The separation of the eastern African coast from the Madagascar-Seychelles-Mascarene group was a posteriori justified by the results of species-richness analysis.

\subsection{Analysis of reef fish checklists}

Checklists of reef fishes were obtained as detailed previously (Kulbicki et al., 2013a; Parravicini et al., 2013; Pellissier et al., 2014; Supplementary material, Table S1). Checklists of fishes from Australia were obtained from the Atlas of Living Australia website. Only fish species associated with either coral reefs or rocky reefs were retained for our analyses. For each species, size was obtained from FishBase (Froese and Pauly, 2013) and from other sources (see all references under label "General" in Supplementary material, Table S1). A geographic-range index was obtained for each species by counting the number of checklists on which it was found. A total of 289 species lists worldwide were used to build this index. Species lists were grouped into 10 Indian-Ocean provinces (Fig. 1). The geographic locations of checklist sites are given in Supplementary material, Table S1.

Species-richness analyses were restricted to reef fish checklists from the Indian-Ocean region. These checklists suggest that the WIO could be split into two sub-provinces, namely the eastern African (EAF) sub-province, and the Madagascar-Seychelles-Mascarene Islands (WII, for Western Indian Ocean Islands) sub-province. As confirmed by the present work, these sub-provinces show distinct patterns of reef fish endemism. Therefore, to explain some of the patterns we considered EAF and WII as separate biogeographic entities. Species were classed into four main categories of endemism according to their geographical range: (i) "local endemics", i.e. species known from only one checklist; (ii) "province endemics", i.e. species known from only two checklists within a province; (iii) "regional endemics", i.e. species known from three to five checklists; (iv) "non endemics", i.e. species found in six or more checklists. Species found on checklists from non-adjacent biogeographical provinces were not considered endemics.

\subsection{Nucleotide-sequence data}

We compiled mitochondrial nucleotide-sequence datasets for eight species or species complexes that matched the following criteria: (1) having a wide Indo-Pacific distribution; (2) being sampled in both the Indian and the Pacific Oceans; (3) having sampling localities in the Indian Ocean including, but not limited to, the WIO. The following species were selected: the humbug damselfish Dascyllus abudafur (Perciformes: Pomacentridae) and its Pacific-Ocean sibling Dascyllus aruanus, the areolate grouper Epinephelus areolatus (Perciformes: Serranidae), the blacktip grouper Epinephelus fasciatus, the honeycomb grouper Epinephelus merra, the bluespotted cornetfish Fistularia commersonii, the bluestripe snapper Lutjanus kasmira (Perciformes: Lutjanidae), the spiny lobster Panulirus homarus (Decapoda: Palinuridae), and the crescent grunter, Terapon jarbua (Perciformes: Teraponidae). The sequence datasets used for these species were gathered from previous projects of ours (Muths et al., 2012; Borsa et al., 2014; Liu et al., 2014; Muths et al., 2015), together with homologous sequences from the literature (Ward et al., 2005; Kawahara et al., 2008; Gaither et al., 2010; Asgharian et al., 2011; Lakra et al., 2011; Zhang, 2011; Hubert et al., 2012; Jeena, 2013; Zhuang et al., 2013; Alcantara and Yambot, 2014; Lavergne et al., 2014; Lavery et al., 2014; Schoelinck et al., 2014; Senevirathna and Munasinghe, 2014; Jackson et al., 2015), from the Cryobank barcode database (http:// cryobank.sinica.edu.tw/) and from the GenBank nucleotidesequence database (http://www.ncbi.nlm.nih.gov/). New 

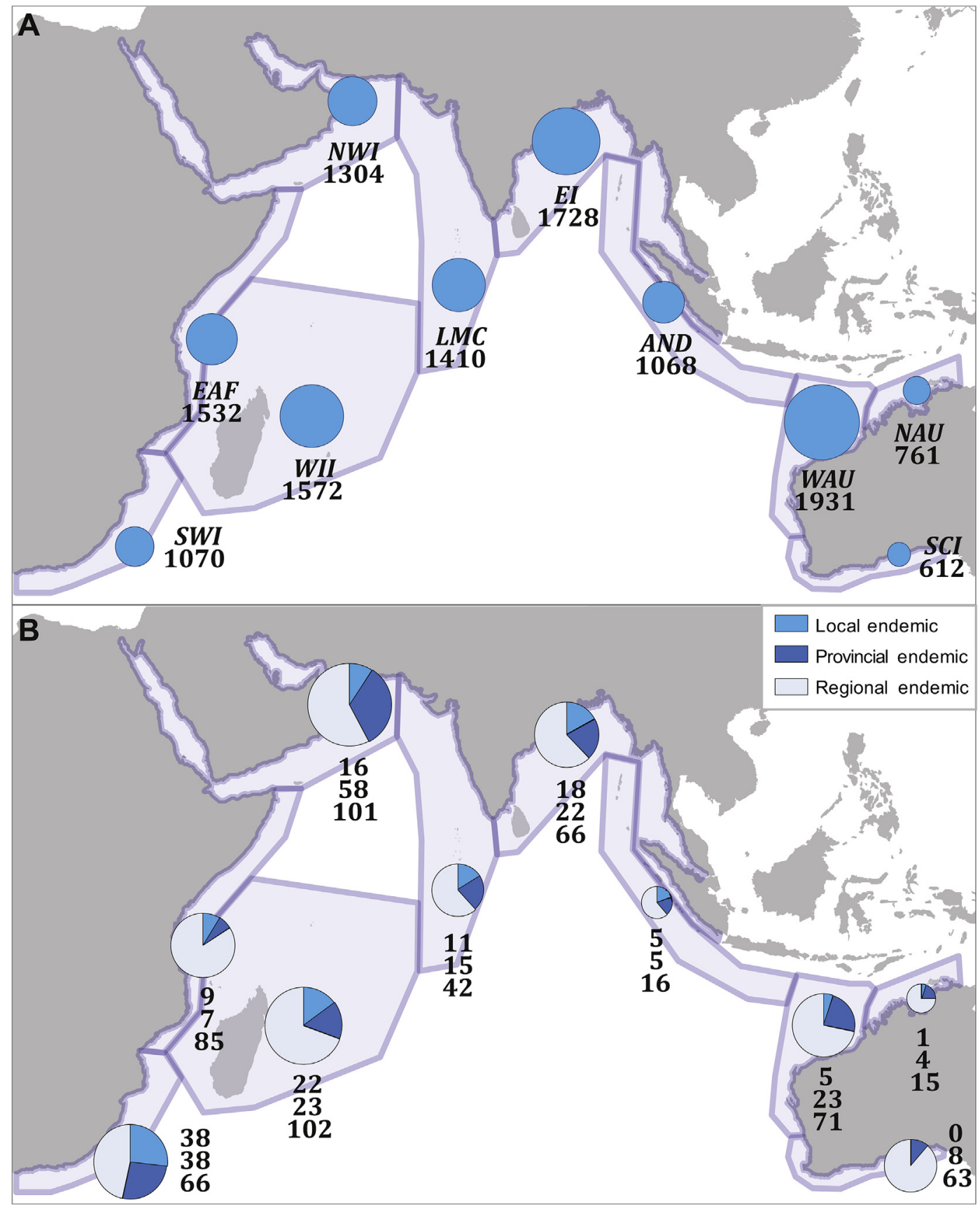

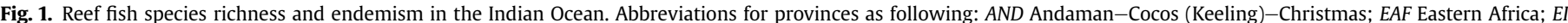

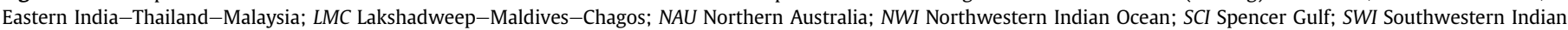

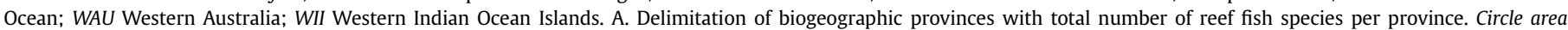

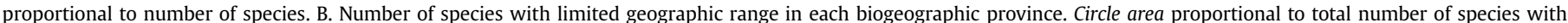

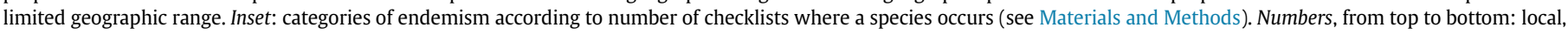
provincial, and regional endemics.

cytochrome $b$ gene sequences of $6 D$. aruanus individuals from Madang, Bismarck Sea were produced according to the methods and protocols detailed in Liu et al. (2014). New CO1 gene sequences were produced for E. fasciatus from Glorieuses Islands, Iles Eparses $(N=1)$, as well as $T$. jarbua from Iles Eparses $(N=7)$, Vietnam $(N=3)$, and Taiwan $(N=10)$. For this, genomic DNA was extracted using the PureLink ${ }^{\circledR}$ Genomic DNA Mini Kit (Life Technologies, Carlsbad CA) and a set of three primers (FishF1, FishF2 and FishR1;
Ward et al., 2005) was used to PCR-amplify a 650-bp fragment of the $\mathrm{CO} 1$ gene. Purification of PCR products and sequencing were done by Macrogen (Amsterdam). Cryobank and GenBank accession numbers are provided in Appendix A. Sequences were edited using the 4Peaks DNA sequence file viewer software (Mekentosj.com, Amsterdam; Griekspoor and Groothuis, 2005).

For each species, sequences were aligned and trimmed to a common length under BioEdit ver. 7.1.11 (Hall, 1999). 


\subsection{Nucleotide-sequence data analysis}

Median-joining parsimony networks were constructed using Network ver. 4.6.1.3 (Bandelt et al., 1999), based on the matrices of individual nucleotide sequences; the default settings of the program were selected. Nucleotide distances between haplogroups were estimated using Mega6 (Tamura et al., 2013), based on the most likely nucleotide substitution model according to the Bayesian information criterion. The model chosen for the 1058-bp cytochrome $b$ gene fragment in $D$. abudafur/D. aruanus was TN93 + G (Tamura and Nei, 1993). Although the best model determined by Mega6 for the 803-bp cytochrome $b$ gene fragment in E. merra was HKY + G (Hasegawa et al., 1985), the model chosen was the second-best, TN93 $+\mathrm{G}$, which contrary to HKY $+\mathrm{G}$, is available for estimating nucleotide distances in Mega6. The model chosen for the 547-bp CO1 gene fragment in P. homarus was T92 + G (Tamura, 1992). The model chosen for the 475-bp cytochrome $b$ gene fragment in L. kasmira and for the 551-bp CO1 gene fragment in T. jarbua was K2P (Kimura, 1980).

In all networks, we distinguished haplotypes sampled in the Pacific Ocean from those sampled in the Indian Ocean. Within the latter, we distinguished those sampled in the WIO or from tropical South Africa [even though the latter formally belonged to the nearby southwestern Indian Ocean province (SWI) as defined in Section 2.1] from the rest of the Indian Ocean.

Levels of genetic divergence between populations were estimated with the $\Phi_{\mathrm{ST}}$ fixation index (Excoffier et al., 1992) computed using Arlequin 3.5 (Excoffier and Lischer, 2010). For estimating $\Phi_{\mathrm{ST}}$, nucleotide differences were based on the nucleotide substitution model determined as the most likely according to the Bayesian information criterion. Because the HKY model is not implemented in Arlequin, the more inclusive TN93 model was used instead. Significance of $\Phi_{\mathrm{ST}}$ for all possible pairwise population comparisons was assessed using 1000 random permutations.
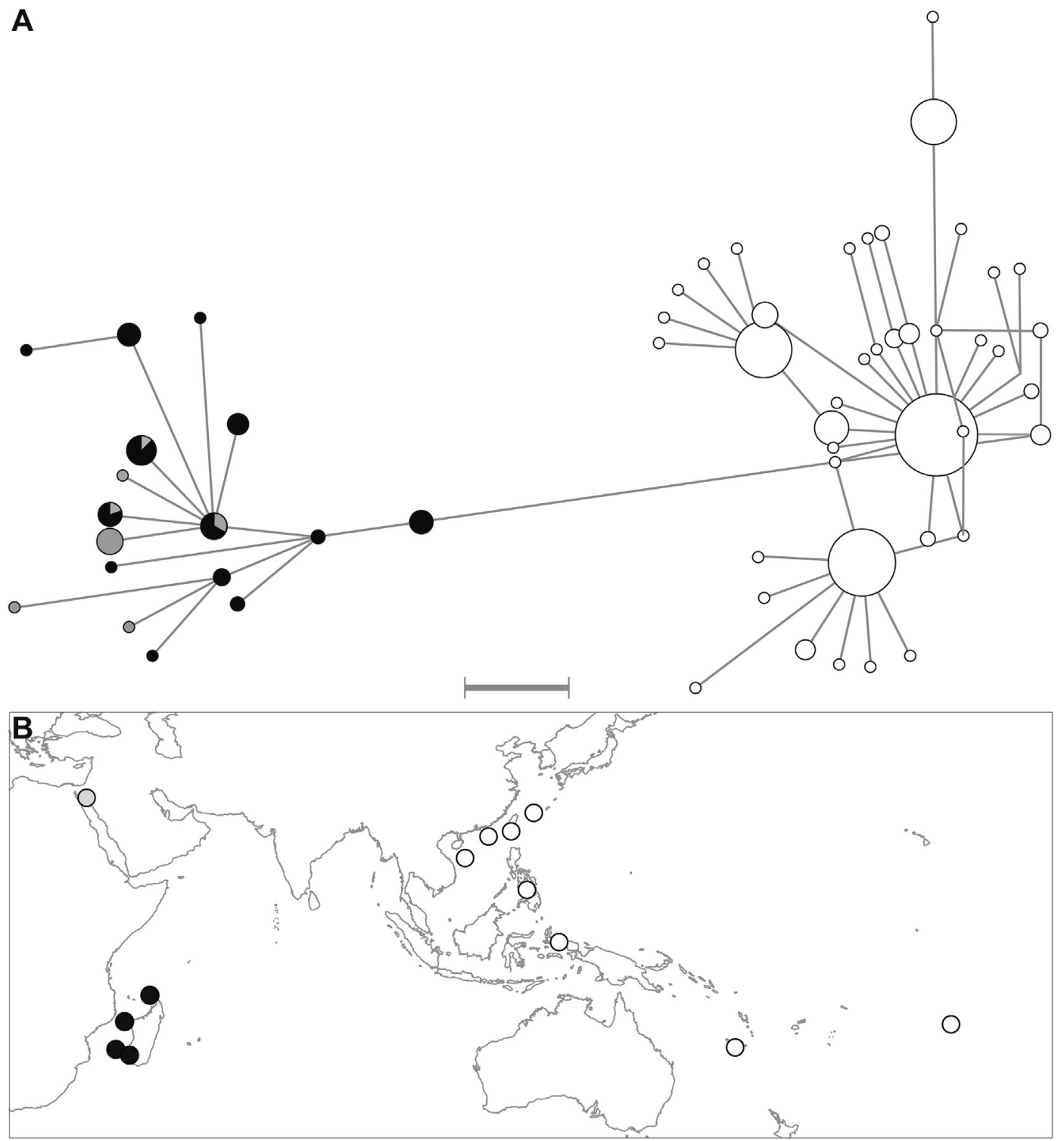

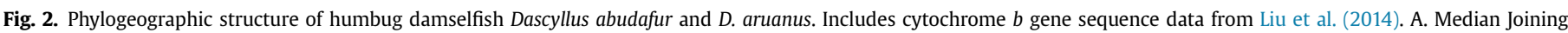

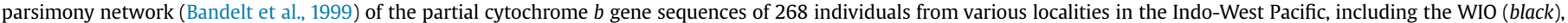

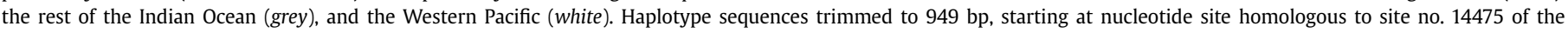
mitochondrial DNA (=no. 46 of the cytochrome $b$ gene) of Abudefduf vaigiensis (GenBank no. NC_009064). Scale bar: one mutational step. B. Sampling locations. 
A
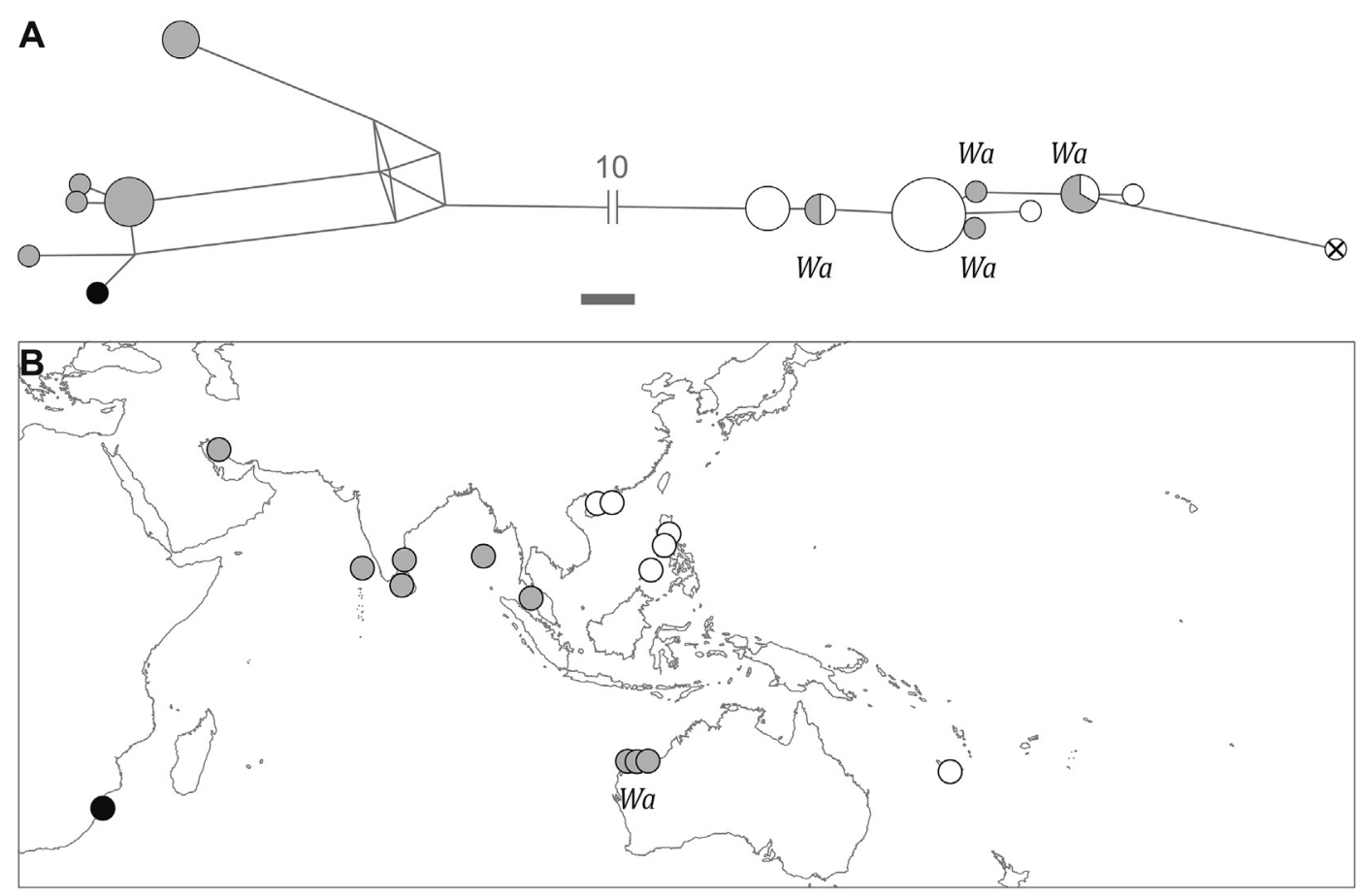

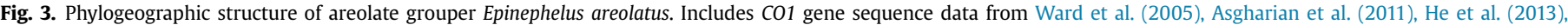

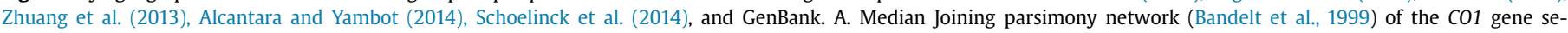

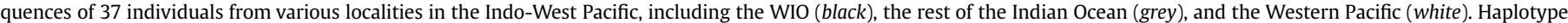

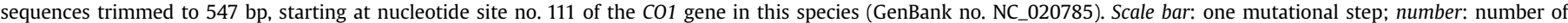

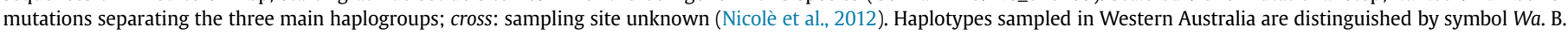
Known sampling locations. Wa Western Australia.

\subsection{Survey of the phylogeographic literature}

The core collection of the Web of Science ver. 2014 (Thomson Reuters, London; http://apps.webofknowledge.com/) was searched for additional articles on the marine phylogeography of the IndoWest Pacific. Combinations of the keywords "Indian", "Pacific" and "phylogeography", or their derivatives, were entered into the "topic" field of the Basic Search tool of the Web of Science. Among the articles thus retrieved, we retained those for which samples from both the Indian and the Pacific oceans were characterized genetically at the mitochondrial locus, including at least one sample from the WIO or tropical South Africa and one sample from the rest of the Indian Ocean. The eligible phylogeographic surveys in reef fishes and invertebrates included the peacock grouper Cephalopholis argus (Gaither et al., 2011), the scrawled butterflyfish Chaetodon meyeri (DiBattista et al., 2012), the cleaner wrasse Labroides dimidiatus (Drew et al., 2008; Sims et al., 2014), the longface emperor Lethrinus sp. A (one of the two biological species formerly under Lethrinus olivaceus; Borsa et al., 2013b), the blue sea star, Linckia laevigata (Crandall et al., 2014), the spotted and bluespine unicornfishes, Naso brevirostris and Naso unicornis (Horne et al., 2008), the bignose unicornfish Naso vlamingii (Klanten et al., 2007), the blue-spotted maskray Neotrygon kuhlii (Arlyza et al., 2013), the common parrotfish Scarus psittacus (Winters et al., 2010), the whitetip reef shark Triaenodon obesus (Whitney et al., 2012), and the small giant clam Tridacna maxima (Hui, 2012). An additional taxonomic survey of species in the family Mugilidae (Durand and Borsa, 2015) provided preliminary insights into the phylogeographies of the bluespot mullet, Crenimugil sp. A (one of the cryptic species under Moolgarda seheli; see Durand et al., 2012), and the largescale mullet, Planiliza macrolepis (formerly Chelon macrolepis; Durand et al., 2012). While grey mullets are generally not understood as coral reef-associated fishes, the habitats of Crenimugil sp. A and P. macrolepis include reef-associated mangroves and reef flats and lagoons.

The topology of the phylogenetic trees of L. dimidiatus mitochondria (Drew et al., 2008; Sims et al., 2014), together with correlated differences in morphology, imply that $L$. dimidiatus consists of two distinctly evolved entities which either have retained morphological and behavioural similarity, or have converged morphologically and behaviourly. It is thus sensible to treat the two forms of L. dimidiatus separately. One form, which corresponds to mitochondrial clade 1 of Sims et al. (2014), is distributed from the western Indian Ocean to the western Pacific Ocean; the other form (clade 2) has so far been sampled exclusively in the southwestern Pacific (Drew et al., 2008; Sims et al., 2014). We examined the phylogeographic structure of the clade 1 form, coined Labroides sp. 1 hereafter.

\section{Results}

\subsection{Species richness patterns inferred from reef fish assemblages}

The total number of reef fish species per province (Fig. 1A; Supplementary material, Table S2) varied from 612 in the subtropical southeastern Indian Ocean province (SCI), to 1931 in the adjacent Western Australian province (WAU). The WIO province $(N=1826)$ had nearly as many species as WAU but it was the largest in size of all Indian Ocean provinces. When we split the WIO into two provinces, namely WII and EAF, the WII had 1572 species and the EAF had 1532. The WIO had a number of reef fish species higher than, or equal to that in the East India-Thailand-Malaysia province (EI) $(N=1728)$, even though the latter is much closer to the Coral Triangle, the epicenter of Indo-West Pacific species richness for reef fishes (Briggs, 2003; Bellwood et al., 2005; Allen and Erdmann, 


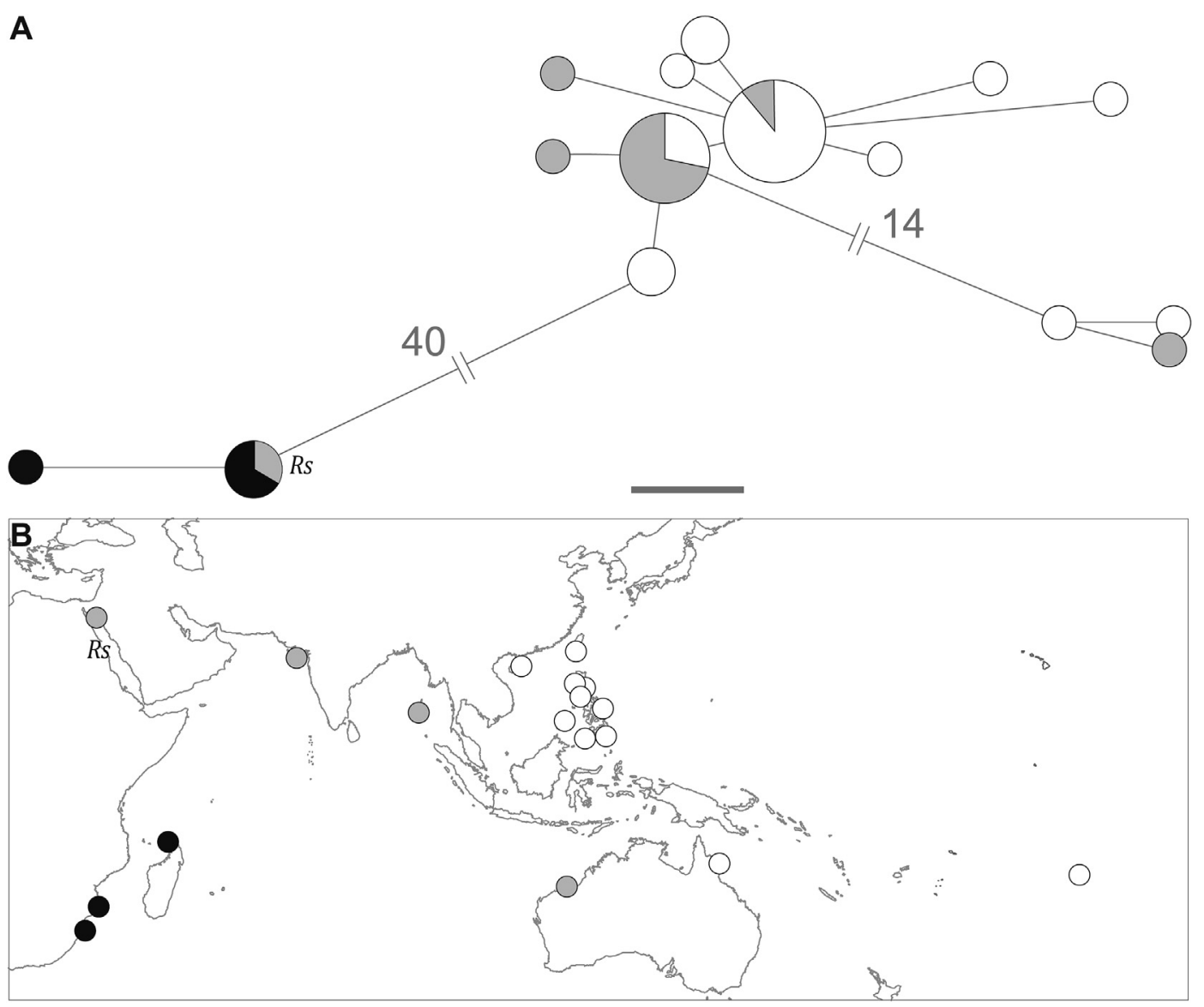

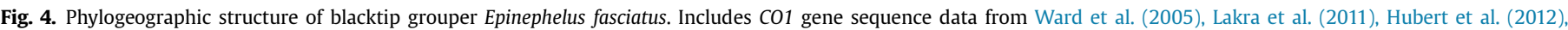

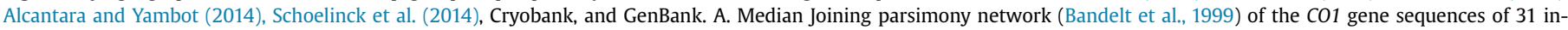

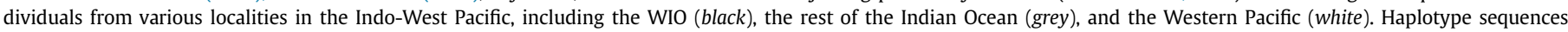

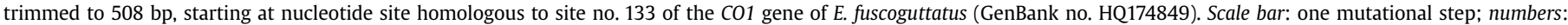
numbers of mutations separating the three main haplogroups. The single haplotype sampled in the Red Sea is distinguished by symbol Rs. B. Sampling locations. Rs Red Sea.

2012). Species richness in the WII sub-province was also higher than in the northwestern Indian Ocean (NWI) province. No gradient in species richness was observed among provinces.

The number of endemic species was much higher in the WIO than in any other region of the Indian Ocean (Fig. 1B; Supplementary material, Table S2). The WIO also had a high percentage of endemics (11.2\%), close to those of the Red Sea/NWI province $(13.4 \%)$ or the SWI province (13.3\%). The majority of these endemics were regional endemics. No correlation was found between the number of endemics, or their proportion or their level of endemism, and seasurface temperature, reef area, island size, degree of isolation, or distance to the Coral Triangle (as the assumed epicenter of Indo-West Pacific marine species richness). Within the WIO, endemic species were more abundant and more frequent in the WII than in the EAF. In the latter, the numbers and proportions of local and provincial endemics were among the lowest in the Indian Ocean.

Endemic reef fish species showed among-region variation in size distributions (Supplementary material, Fig. S2). The WIO displayed a heterogeneous composition, with the size distribution of endemic species in the EAF being rather similar to that in SWI. Both EAF and SWI had larger endemic species than the other regions of the Indian Ocean. All the other provinces were dominated by small endemic species (with a peak in size at 5-10 cm). However, the WII also showed a mode at $15-30 \mathrm{~cm}$, like the continental African provinces, suggesting that similar processes may be at play in EAF, WII and South Africa.

\subsection{Multiple-species phylogeographic survey}

In the pair D. abudafur/D. aruanus, mitochondrial haplotypes were split into two main haplogroups (Fig. 2) separated by $0.6 \%$ net nucleotide distance. One haplogroup comprised all haplotypes sampled in the Indian Ocean, the other one comprised all haplotypes sampled in the Pacific Ocean. Most haplotypes from the Red Sea, all private, formed a sub-lineage nested within the WIO haplogroup. This suggests that Red Sea haplotypes derive from either the WIO, or from a geographically larger population that encompasses the WIO. Population-pairwise $\Phi_{\mathrm{ST}}$ estimates (Supplementary material, Table S3) showed no heterogeneity within the WIO ( $\Phi_{\mathrm{ST}}$ not significantly different from 0 ), while all comparisons between WIO populations and the other Indian-Ocean population, i.e. the Red Sea $(\mathrm{RS})\left(\Phi_{\mathrm{ST}}=0.353-0.386\right)$ were highly significant, indicating strong restriction in gene flow.

Strong phylogeographic structure was also evident in E. areolatus (Fig. 3). The only haplotype sampled in the WIO clustered with the other Indian-Ocean haplotypes (except those sampled in Western Australia) whereas all Pacific-Ocean haplotypes clustered together with Western Australian haplotypes as a separate haplogroup. Three distinct haplogroups were observed in E. fasciatus (Fig. 4A). The longest branch of the network separated haplotypes found exclusively in the WIO and the Red Sea, from the rest, i.e. from the central and eastern Indian Ocean and from the Pacific Ocean. No clear geographic segregation was observed within the 

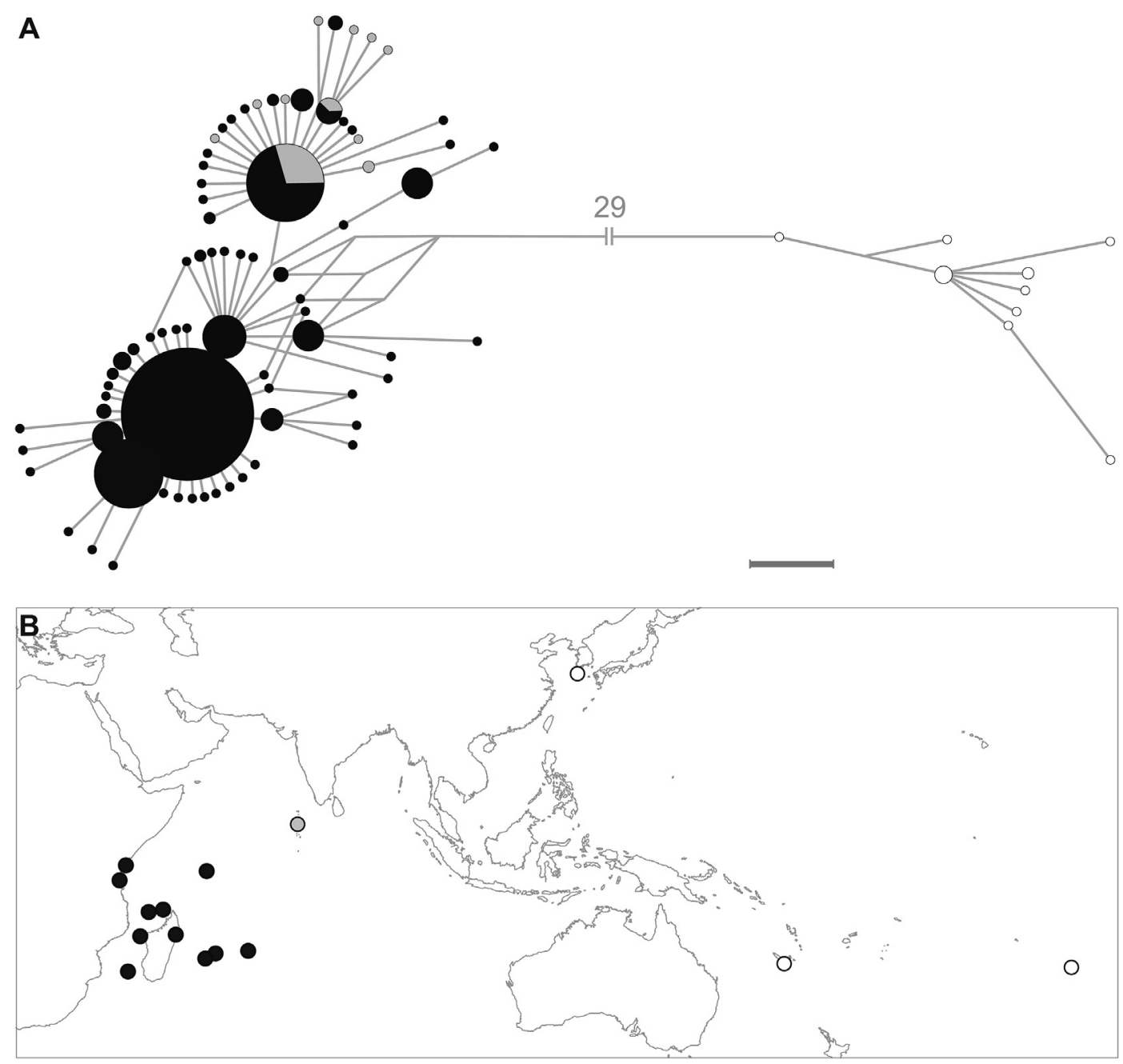

Fig. 5. Phylogeographic structure of honeycomb grouper Epinephelus merra. Includes cytochrome $b$ gene sequence data from Muths et al. (2015), and GenBank. A. Median Joining parsimony network (Bandelt et al., 1999) of the cytochrome $b$ gene sequences of 487 individuals from various localities in the Indo-West Pacific, including the WIO (black), the rest of the Indian Ocean (grey), and the Western Pacific (white). Haplotype sequences trimmed to $803 \mathrm{bp}$, starting at nucleotide site homologous to site no. 61 of the cytochrome $b$ gene of E. costae (GenBank no. DQ197951). Scale bar: one mutational step; number indicates the number of mutations separating the two main haplogroups. B. Sampling locations.

latter ensemble, although haplotypes from different geographic origins were apparently not distributed randomly. Most haplotypes from the Coral Triangle clustered around the dominant haplotype, while the second-dominant haplotype mostly comprised haplotypes from the central and eastern Indian Ocean. The mitochondrial haplotype network produced for E. merra (Fig. 5A) can be easily superimposed on the map of samples (Fig. 5B), indicating phylogeographic structure. An Indian vs. Pacific phylogeographic partition was evident, where haplogroups from the two oceans were separated by $4.6 \%$ nucleotide distance, pointing to a geographic barrier between the two mitochondrial forms. The geographic barrier is located east of the Maldives and west of New Caledonia. Indian-Ocean haplotypes clustered into two distinct haplogroups, each centered around a dominant haplotype in a star-like fashion. One of the two haplogroups exclusively comprised haplotypes sampled from the WIO. The other haplogroup, which appeared to be an offshoot of the first haplogroup, comprised all haplotypes sampled in the Maldives together with a proportion of WIO haplotypes. In other words, the Maldives haplogroup was nested within the WIO haplogroup, suggesting past asymmetrical gene flow from the WIO, or from a geographically larger population encompassing the WIO, towards the central Indian Ocean. Population-pairwise $\Phi_{\mathrm{ST}}$ estimates (Supplementary material,
Table S4) indicated substantial heterogeneity within the WIO (with $\Phi_{\mathrm{ST}}$ up to 0.344 ) and highly significant differences with the only other sample from the Indian Ocean, i.e. the Maldives (MAL) (average $\Phi_{\mathrm{ST}}=0.269 \pm 0.125$ ).

No obvious phylogeographic structure was observed in F. commersonii, although all haplotypes from Baja California clustered as a single branch of the network and the two haplotypes from Reunion Island (WIO) were distant from the rest of the network (Fig. 6).

L. kasmira haplotypes were organized as a star-like network with a dominant central haplotype that was shared between the WIO, the central and eastern Indian Ocean, and the Pacific Ocean. Little heterogeneity in haplotype frequencies was visible overall, except for the occurrence of a derived, predominantly PacificOcean haplogroup (Fig. 7). Population-pairwise $\Phi_{\mathrm{ST}}$ estimates (Supplementary material, Table S5) singled out the Marquesas population $\left(\Phi_{\mathrm{ST}}=0.499-0.627\right)$ but otherwise showed only weak differentiation, with population-pairwise $\Phi_{\mathrm{ST}}$ values ranging from 0 to 0.077 . The $\Phi_{\mathrm{ST}}$ estimates between the WIO and the other Indian-Ocean populations ranged from 0 to 0.050 and were hardly significantly different from 0 considering adjustment for multiple tests (Rice, 1989).

Two major haplogroups were observed in P. homarus, separated by $5.8 \%$ net nucleotide distance at the $\mathrm{CO} 1$ locus (Fig. $8 \mathrm{~A}$ ). While the 

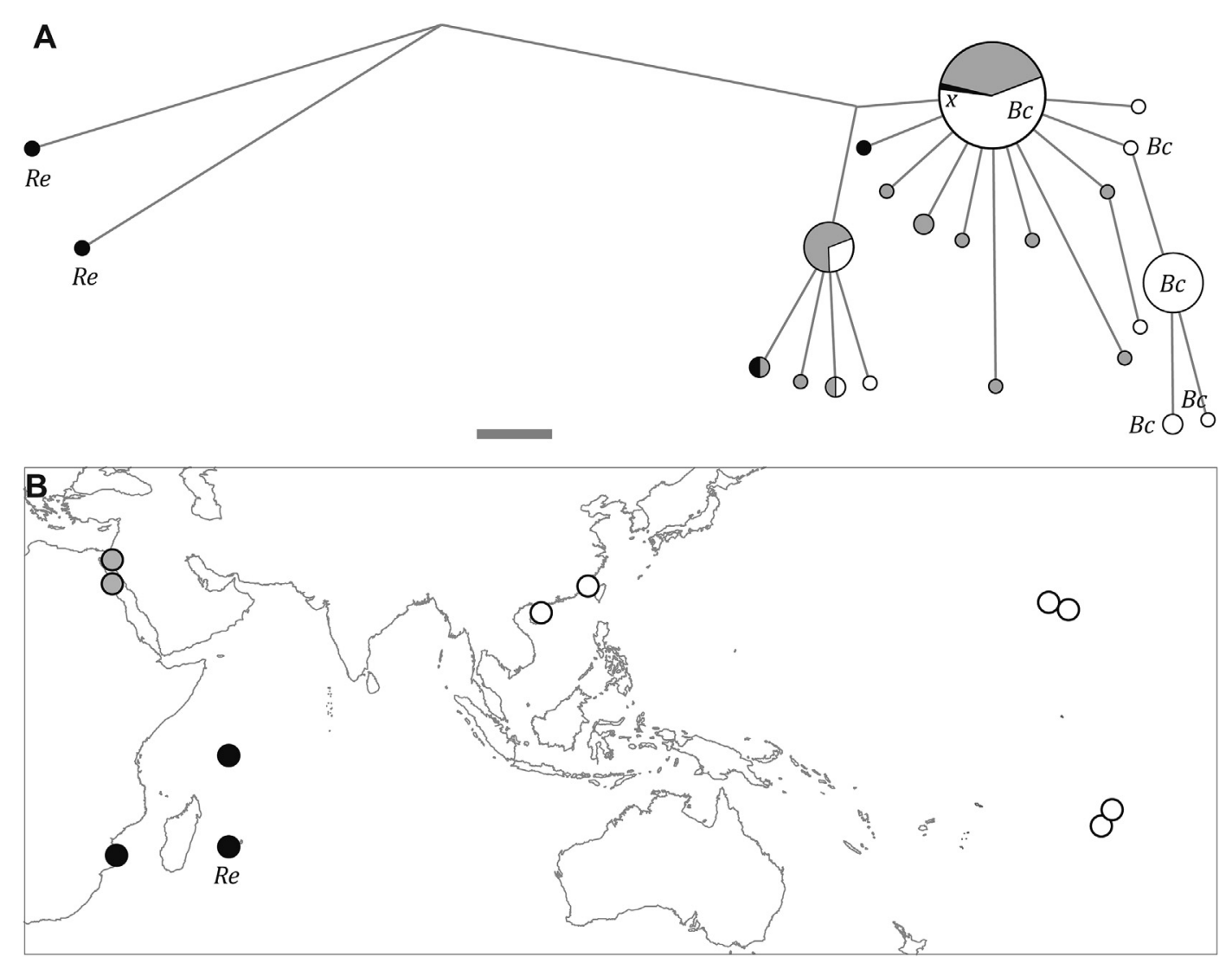

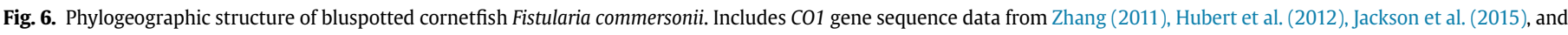

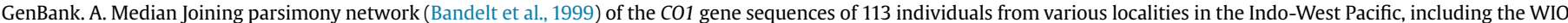

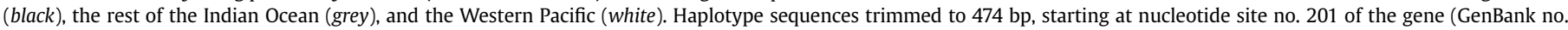

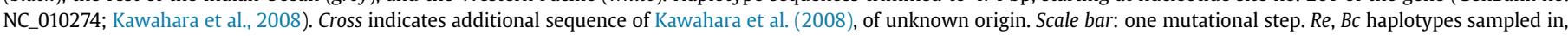
respectively, Reunion Island and Baja California. B. Sampling locations, excluding La Paz, Baja California. Re Reunion Island.

dominant haplogroup included haplotypes from the whole distribution of $P$. homarus, the second haplogroup (delineated by a dashed ellipse on Fig. 8A) comprised haplotypes from the WIO exclusively. The WIO haplogroup, which corresponds to morphological subspecies $P$. $h$. rubellus (Lavery et al., 2014), was discarded for $\Phi_{\mathrm{ST}}$ analysis. At the Indian-Ocean scale, the dominant haplogroup showed no obvious structure, while the $\Phi_{\mathrm{ST}}$ analysis distinguished the northwestern Indian-Ocean samples from all the rest $\left(\Phi_{\mathrm{ST}}=0.108 \pm 0.106\right)$ (Supplementary material, Table S6).

Three main haplogroups were observed in T. jarbua (Fig. 9). A haplogroup that included all haplotypes sampled in Juan de Nova, WIO, together with a haplotype from the Red Sea, was separated from the rest of the nucleotide sequence dataset by $7.6 \%$ net nucleotide distance at the $\mathrm{CO} 1$ locus. Within the latter, a predominantly Indian haplogroup was separated from a predominantly Pacific haplogroup by $2.6 \%$ net nucleotide distance. High levels of genetic differentiation were estimated between populations, but no clear geographic pattern was apparent. The reason for this was the geographically widespread occurrence of the three haplogroups, in variable proportions. The Iles Eparses sample was strongly differentiated from the other populations $\left(\Phi_{\mathrm{ST}}=0.472-0.628\right.$; Supplementary material, Table S7) because all of its individuals harboured the Juan de Nova haplotype which was not sampled elsewhere except in the Red Sea.

\subsection{Additional cases drawn from the phylogeographic literature}

Fourteen additional cases were investigated (Supplementary material, Figs. S3-S14; Durand and Borsa, 2015), eleven of which concerned reef-associated bony fishes. In C. argus, two major haplogroups were observed, with an Indian vs. Pacific phylogeographic partition. However, the 'Indian' haplogroup also harboured haplotypes sampled in the Pacific Ocean and vice versa, suggesting either incomplete lineage sorting, or secondary contact between the two oceans (Gaither et al., 2011). Haplotypes sampled in the WIO were nested within the 'Indian' haplogroup exclusively, suggesting that 'Pacific' haplotypes under Gaither et al.'s (2011) overlap hypothesis have not reached the WIO (Supplementary material, Fig. S3). In C. meyeri (Supplementary material, Fig. S4), only moderate Indian vs. Pacific phylogeographic partition was observed, suggesting weak differentiation between populations from the two oceans. In Labroides sp. 1, a loose Indian vs. Pacific genetic-differentiation was visible (Supplementary material, Fig. S5), compatible with isolation by distance (Wright, 1942). This is the hypothesis favoured by Sims et al. (2014) on the basis of observed correlation-between $\Phi_{\mathrm{ST}}$ and geographic distance. From the limited dataset available in Lethrinus sp. A (Supplementary material, Fig. S6), we observed a clear Indian vs. Pacific phylogeographic partition. In L. laevigata (Supplementary material, Fig. S7), two major clusters of haplotypes were observed, one of which included a few WIO haplotypes. This cluster included a substantially higher proportion of Indian-Ocean haplotypes than the other cluster, which was predominantly Pacific. The dominant WIO haplotypes occupied a central position in the network, implying that one, the other, or possibly both, of the two major haplogroups may derive from an ancestral WIO stock. No phylogeographic structure was observed in $N$. brevirostris, $N$. unicornis 

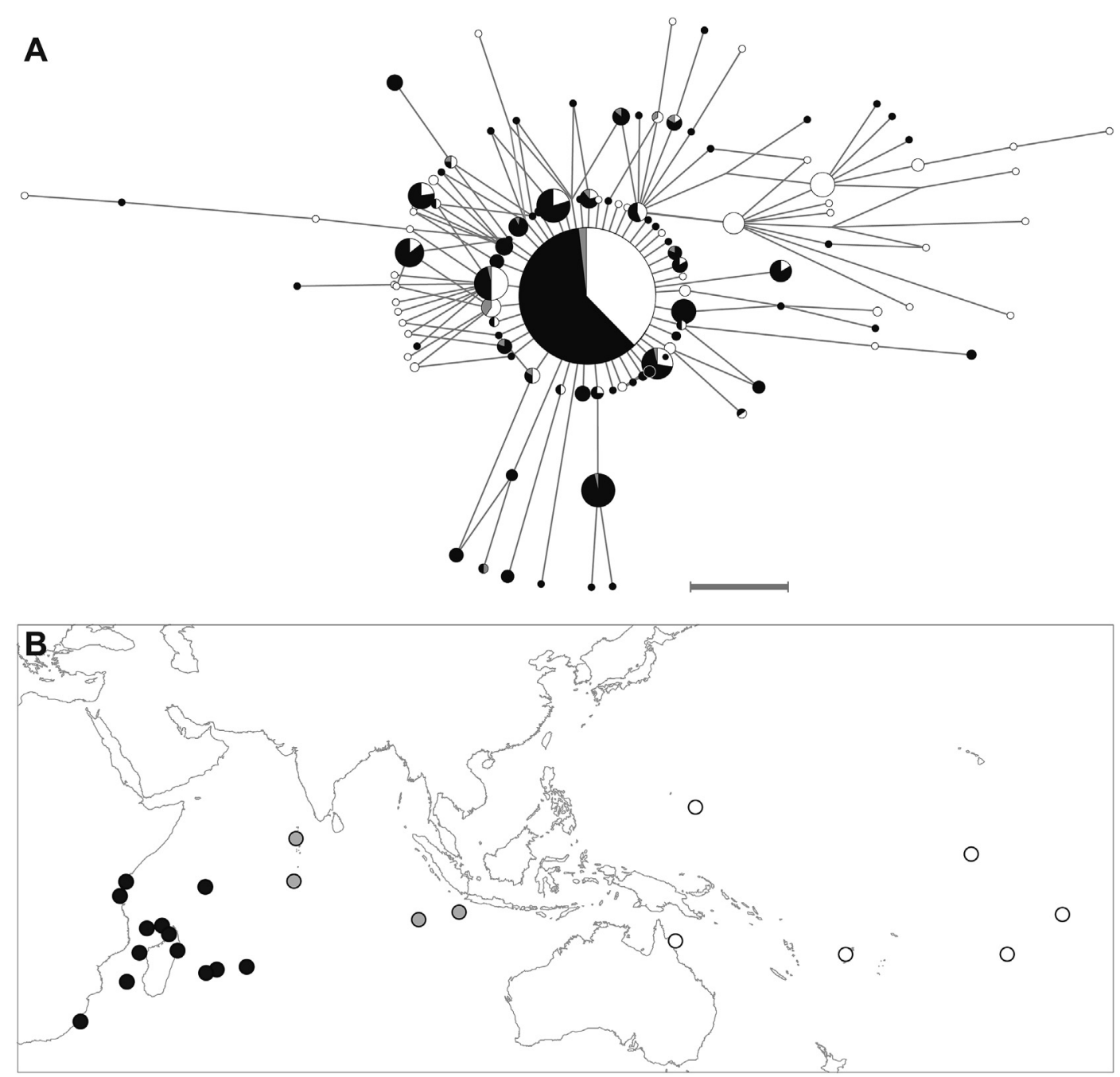

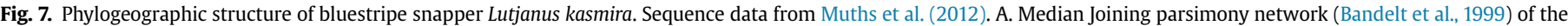

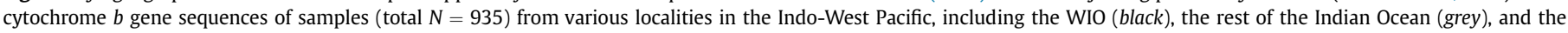

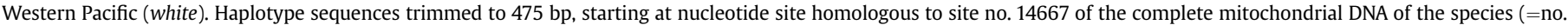
274 of the cytochrome $b$ gene) (GenBank no. NC_011578). Scale bar: one mutational step. B. Sampling locations.

and N. vlamingii (Supplementary material, Figs. S8-S10). No phylogeographic structure was visible from the haplotype network in $S$. psittacus (Supplementary material, Fig. S12) although peripheral genetic differentiation has been reported. Genetic differences in $T$ obesus indicated geographic isolation between populations either side of the Indo-Pacific barrier (Supplementary material, Fig. S13). Strong phylogeographic structure was observed in T. maxima across the Indo-Pacific barrier and within the Indian Ocean (Supplementary material, Fig. S14). Within the Indian Ocean, three distinct T. maxima clades were evident from maximum-likelihood analysis. One clade corresponded to Hui's (2012) clade 5, exclusively found in the WIO; a second clade corresponded to Hui's (2012) clade 2, exclusive to the eastern Indian Ocean and the Sunda Shelf; a third clade corresponded to Hui's (2012) clades 4 and 6 from the WIO and the Red Sea (Supplementary material, Fig. S14). Similarly strong, parapatric geographic structure was observed in $N$. kuhlii, where 7 clades had been sampled by Arlyza et al. (2013), all from the sole Coral Triangle region (Supplementary material, Fig. S11). The two N. kuhlii haplotypes sampled from the WIO formed a lineage distinct from all other sites sampled in the Indian Ocean and on the Indian-Ocean side of the Coral Trangle.

In addition, little genetic differentiation was evident in
Crenimugil sp. A, where the same mitochondrial haplotype was sampled from the WIO to the southwestern Pacific. However, a distinct sub-clade from the northwestern Indian Ocean was observed (Durand and Borsa, 2015). In P. macrolepis, haplotypes sampled in the Maldives and further east belonged to a clade distinct from haplotypes sampled in the western and northwestern Indian Ocean (see figures 1A and 4E of Durand and Borsa, 2015).

\section{Discussion}

\subsection{Species diversity and endemism patterns}

The WIO showed higher reef-fish species richness than provinces geographically closer to the Coral Triangle, the epicenter of species richness in the Indo-West Pacific, for reef fishes (Briggs, 2003; Bellwood et al., 2005; Allen and Erdmann, 2012) and more generally for the coastal marine fauna and flora (Sanciangco et al., 2013). This was unexpected for several reasons. First, the number of species usually decreases as distance from the biodiversity center increases (Briggs, 2003; Parravicini et al., 2013). Pellissier et al. (2014) proposed that this is in part due to evolutionary history, with regions close to the assumed diversity center also being close 

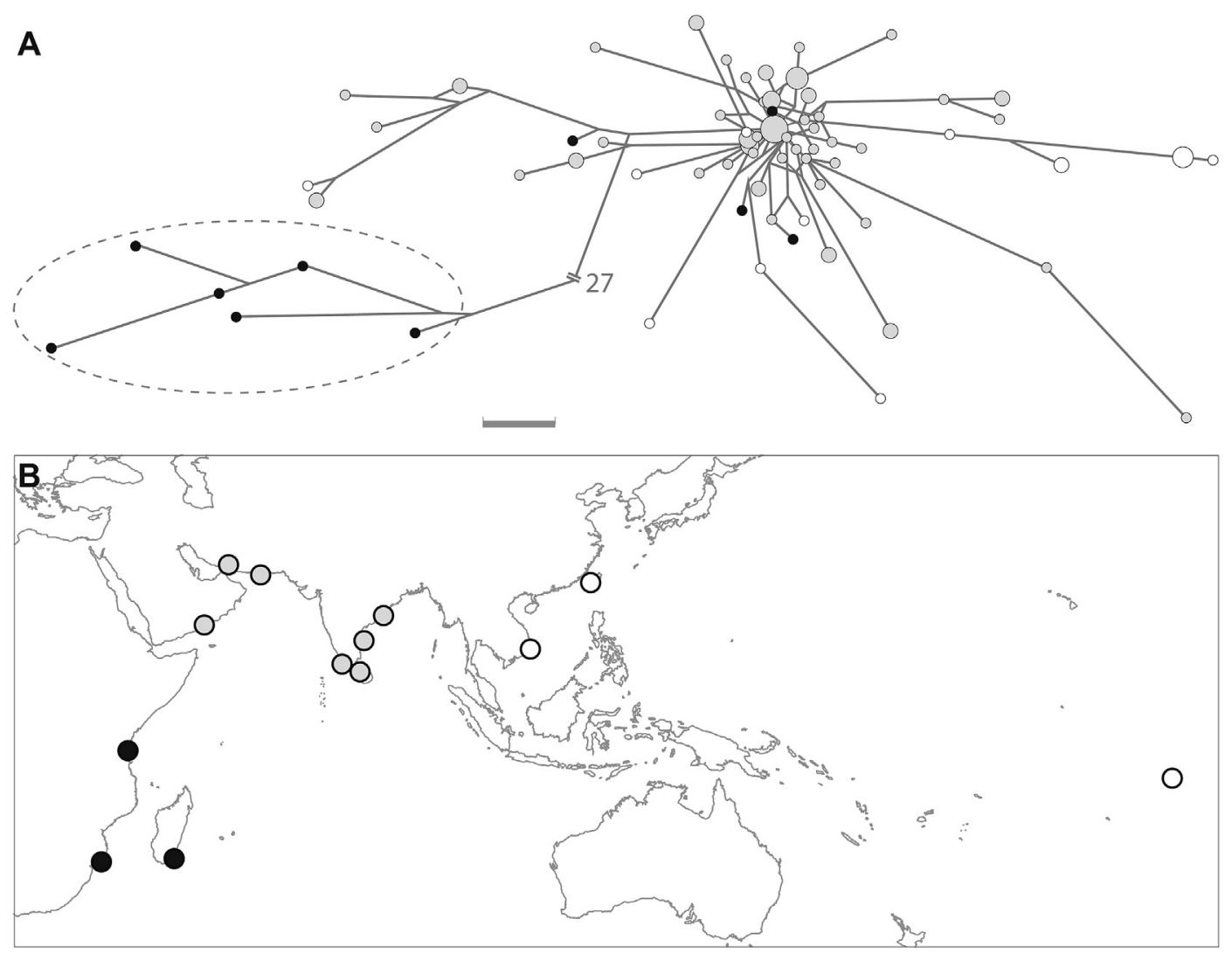

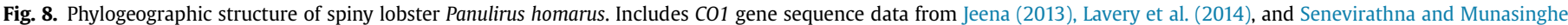

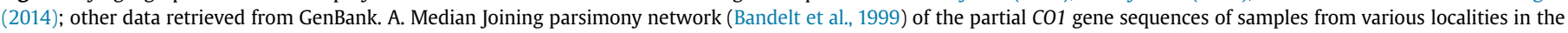

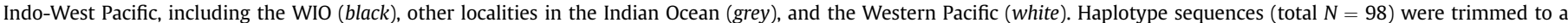

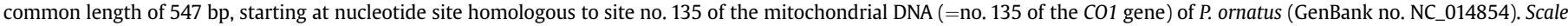
bar: one mutational step; numbers indicates the number of mutations separating the two main haplogroups. B. Sampling locations.

to coral refuges during cold climate episodes. In addition, the WII has many small islands which typically harbour low species richness, because species richness decreases with island size (Parravicini et al., 2013). One would therefore expect fewer species in the WII than on the continental shelf of Africa (EAF and SWI). We observed the opposite.

The number of endemic species in the WIO was higher than in the northwestern part of the Indian Ocean (NWI province), as already shown by Kulbicki et al. (2013a), despite the fact that NWI has the highest rate of local endemism in the Indo-Pacific after Easter Island and Hawaii (Allen, 2008). We do not know if these endemic species are of local origin or if they are relicts from wider, past distributions. Dedicated phylogeographic surveys of these endemic species, that would also examine phylogenetically related species would help uncover their origin(s). The analysis of bodylength distributions nevertheless provided some interesting information. Along the western shores of the Indian Ocean (NWI, EAF, $\mathrm{SWI}$ ), endemic species were larger than elsewhere in the Indian Ocean. This is to be related to a similar situation in Hawaii where local endemics are larger than endemics in other parts of the Pacific Ocean (DeMartini and Friedlander, 2004). Hawaii, just as the eastern African coast, lies at the edge of its realm. Species size is a primary determinant of species distribution and large species tend to be better dispersers and better colonizers than small species (Luiz et al., 2013). As a consequence, larger species are more frequent in assemblages on small or remote islands, just as in the present case off the eastern African coast. In the other part of the WIO, WII endemics are, in majority, small species, although with a second mode of larger species. This suggests a complex origin for endemics. Small-size endemics dominate in the northwestern part of the Indian Ocean, which suggests that the continental or island coastal type was not a major determinant of the distribution of sizes. Both the Red Sea and Madagascar held coral reef refuges during the last 3 million years (Pellissier et al., 2014). These refuges could have sheltered small species which subsequently may have not re-colonized a wide range and therefore became endemic.

\subsection{Variability in phylogeographic structure}

As shown by the case studies used for the present review, geographic sampling design in phylogeographic surveys of IndoWest Pacific reef species was mostly uneven and unbalanced. Even the aggregative survey of L. laevigata by Crandall et al. (2014), presented (p. 399) as "one of the most geographically comprehensive genetic studies of any Indo-Pacific species to date", had gaps in its sampling design, with the western and central Indian-Ocean regions being noticeably under-sampled. This, together with the low number of comprehensive case studies available, are weaknesses of the present multiple-species phylogeographic survey.

Remarkable variability in phylogeographic patterns and in intensity of genetic differentiation was observed. In several cases $(D$. abudafur/D. aruanus, E. areolatus, E. merra, Lethrinus sp. A, T. maxima), a marked Indian vs. Pacific partition was observed, suggesting geminate species formed by allopatry on either side of the IndoPacific barrier. Weaker Indian vs. Pacific phylogeographic partition was apparent in C. argus, Labroides sp. 1 and L. laevigata, which could 

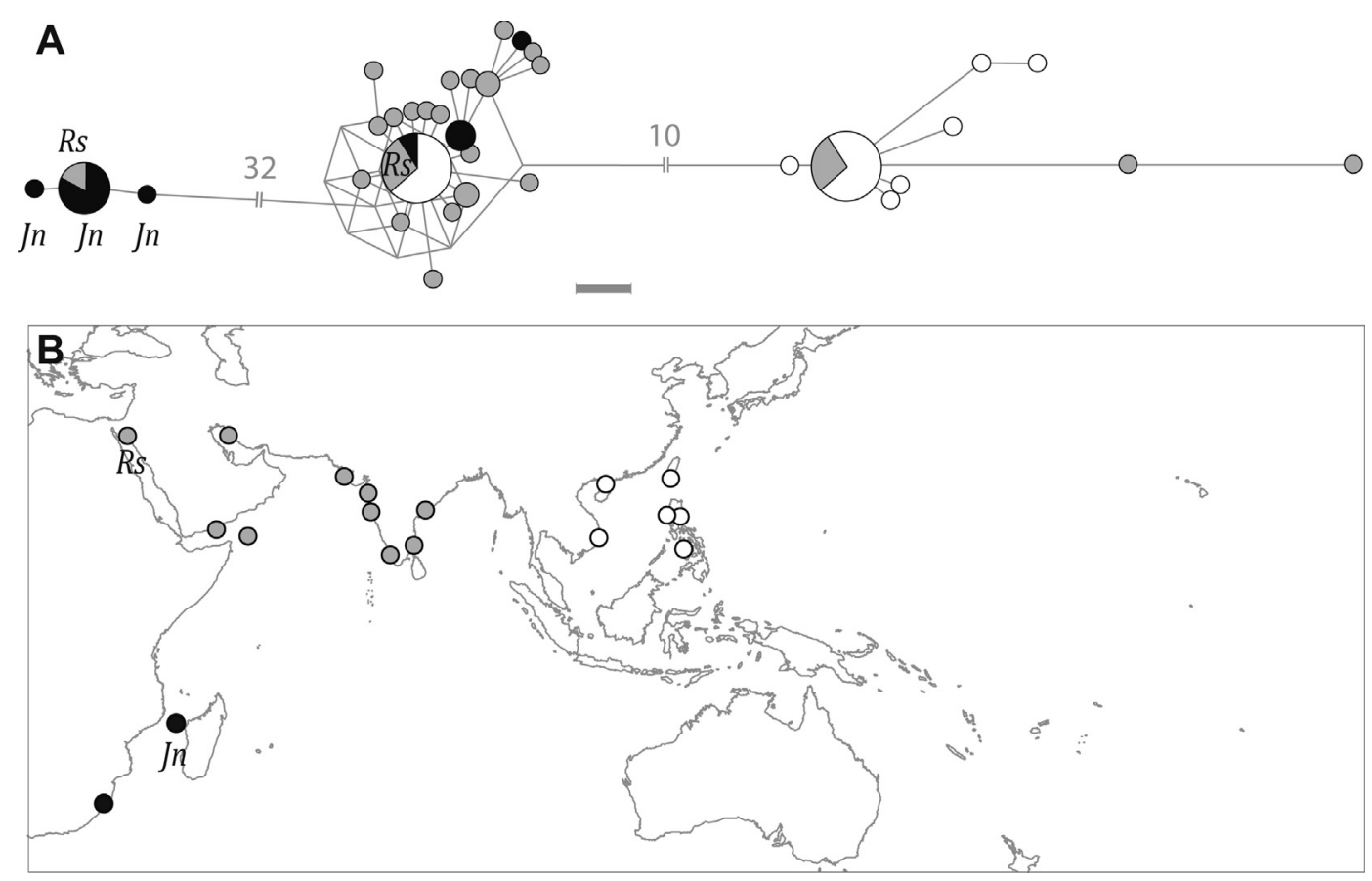

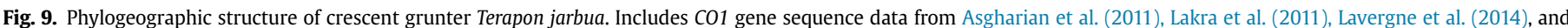

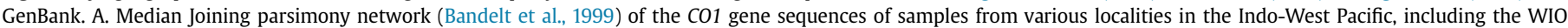

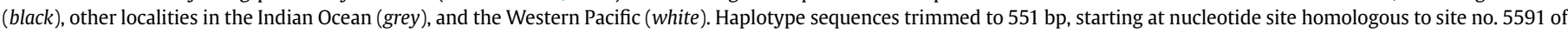

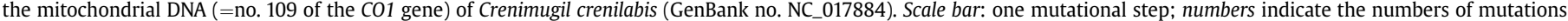

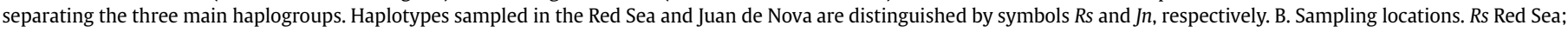
Jn Juan de Nova.

result either from secondary contact and incomplete rehomogenization across the Indo-Pacific barrier ( $C$. argus; Gaither et al., 2011), incomplete lineage sorting, or isolation by distance. In all three cases, as in a number of other cases from the phylogeographic literature reviewed by Carpenter et al. (2011) and Gaither and Rocha (2013), the phylogeographic structure was consistent with incipient genetic divergence of Indian vs. Pacific populations. Among reef-associated animals, this also includes the neritid snail Nerita albicilla (Crandall et al., 2008) and the bigscale soldierfish Myripristis berndti (Muths et al., 2011). Another phylogeographic break located in the mid-Indian Ocean was observed in both E. fasciatus and P. macrolepis. In these and several of the above cases, the western Indian Ocean populations showed phylogeographic originality compared to the eastern Indian Ocean populations, presumably because of the geographic-isolation effect of the mid-Indian Ocean oceanic barrier west of the Lakshadweep-Maldives-Chagos archipelagoes.

Little phylogeographic structure was evident in F. commersonii, where the dominant haplotypes were present in all regions sampled. No phylogeographic structure was detected in seven other species, namely C. meyeri, Crenimugil sp. A, L. kasmira, $N$. brevirostris, $N$. unicornis, $N$. vlamingii, and P. homarus (P. h. rubellus and the Marquesas sub-lineage excluded). Among reef fishes, Chaetodon ornatissimus (the sister-species of C. meyeri; DiBattista et al., 2012), F. commersonii, L. kasmira and Naso lituratus (congeneric with $N$. brevirostris and $N$. vlamingii, and sister species to $N$. unicornis; Klanten et al., 2004) have pelagic larval durations $>30 \mathrm{~d}$, i.e. longer than the other reef fishes considered in this review (see Supplementary material, Table S8). The D. abudafur/D. aruanus species pair, which had the highest levels of population differentiation, is also among those with the shortest pelagic larval duration (18.6-24.3 d). However, this handful of case studies is not sufficient to draw conclusions on a possible effect of pelagic larval duration on phylogeographic structure in Indian-Ocean reef fishes. Complex phylogeographic structure was uncovered in T. jarbua, where the WIO, the northwestern Indian Ocean, and the Coral Triangle might be centers of diversification. One may suspect that T. jarbua actually consists of two, perhaps three biological species whose geographic distributions partly overlap. This possibility cautions against interpreting $\Phi_{\mathrm{ST}}$ estimates without prior sorting of samples by species.

The relative lack of consistency in the phylogeographic structures apparent from the 22 cases that we examined precludes any generalization about the evolutionary processes that have shaped the phylogeographic structure of species in the WIO. More research is certainly necessary to possibly draw generalities, and possibly alter this conclusion. Nevertheless, novel information arose from the present review. For instance, the observed phylogeographic structures in some species (D. abudafur, E. merra, L. laevigata) tended to designate the WIO as a possible source of haplotypes. The WIO also harboured endemic clades in P. homarus ( $P$. h. rubellus) and in T. maxima, suggesting either long-term past geographic isolation or unique ecological characteristics suitable to the latter.

\subsection{Need for taxonomic updates}

Previous phylogeographic work has shown that several widespread Indo-West Pacific reef species actually consist of distinct evolutionary units that qualify as separate species (e.g. Wörheide et al., 2008; Fauvelot and Borsa, 2011; Vogler et al., 2012; Borsa et al., 2013a; Hoareau et al., 2013; Huelsken et al., 2013). This is also the case of $D$. aruanus which is now recognized to consist of the geminate Indo-Pacific species pair D. abudafur/D. aruanus (Borsa et al., 2014), and of $L$. dimidiatus (Sims et al., 2014; see Section 2.4), whose pattern of cryptic speciation parallels that of L. olivaceus (Borsa et al., 2013b). L. olivaceus consists of two biological species 
provisionally designated as Lethrinus sp. A in the Indo-West Pacific, and Lethrinus sp. B, from the western and central Pacific (Borsa et al., 2013b). The subspecies of $P$. homarus endemic to the WIO, $P$. h. rubellus, should similarly be raised to the species status, because of concurring morphological and genetic distinctness (Lavery et al., 2014). Hypothesizing that the distinction of the rubellus form pertains to intraspecific variation does not hold given the long pelagic larval stage in $P$. homarus which lasts up to several months, as in other Panulirus species (Goldstein et al., 2008; Phillips and Matsuda, 2011). It has also been argued that the western and northwestern-Indian Ocean clade of $P$. macrolepis represents a species distinct from the populations east of the mid-Indian Ocean barrier, for which the provisional species name Planiliza sp. H has been proposed (Durand and Borsa, 2015). The present study highlights additional cases where the current taxonomy of species may not reflect their evolutionary history, thus flagging potential cryptic species. For instance, E. areolatus, E. merra and Lethrinus sp. A may each consist of a pair of geminate Indian/Pacific species. Phylogeographic patterns in E. fasciatus (present work) lead us to similarly hypothesize two cryptic species separated by the mid-Indian Ocean barrier. One of the potential biological species under T. jarbua appears to be endemic to the western and northwestern Indian Ocean. Taxonomic investigations of $N$. kuhlii and T. maxima are also warranted.

Based on preliminary barcoding surveys, the occurrence of cryptic species might well occur in up to $30 \%-60 \%$ of Indo-WestPacific reef fishes (Zemlak et al., 2009; Hubert et al., 2012). If this is confirmed by further taxonomic investigations, the species checklists at the basis of a number of recent advances in the biogeography and ecology of reef fishes (e.g. Bellwood et al., 2005; Bellwood et al., 2012; Kulbicki et al., 2013a; Mouillot et al., 2013; Parravicini et al., 2013; Pellissier et al., 2014) will likely become partly obsolete. Consequently, the delineation of biogeographic provinces evoked in the present paper might also have to be revised. However, if most of the additional cryptic species result from thus-far neglected Indian vs. Pacific differences, it is unlikely that the partition into biogeographic provinces within each ocean will change drastically from the current one.

\section{Authors' contributions}

Designed the study: PB, WJC, JDD, MK. Contributed samples/ materials/analysis tools: PB, WJC, JDD, MK, GMT, DM. Analysed and interpreted the data: PB, JDD, MK, DM. Wrote the paper: $\mathrm{PB}, \mathrm{NH}$, MK. All authors read and approved the final manuscript.

\section{Acknowledgements}

This research was supported by France's “Iles Eparses" program (2011-2013) managed by CNRS-Institut écologie et environnement (InEE) with the financial support of CNRS-InEE, CNRS-Institut national des sciences de l'univers (INSU), Institut de recherche pour le développement (IRD) and Agence des aires marines protégées (AAMP), and with the logistic support of Terres australes et antarctiques françaises (TAAF). It is the product of project PHYLIP on the comparative phylogeography of the benthic reef fauna of Iles Eparses in an Indo-Pacific context. We thank R. Beldade, G. Bernardi, J. Bourjea, K.E. Carpenter, P. Chabanet, T. Changeux, P. Courtès, P. Durville, T. Hoareau, C. Marteau, J. O'Donnell, D. Ponton, J.-F. Silvain, E. Teissier and M. Troussellier for stimulating discussions at various stages of this project. We are grateful to Mark A. Phuong, who kindly accepted to copy-edit the manuscript prior to final submission. We thank G.N. Mahardika (IBRC, Denpasar) for discussions on the taxonomy of Panulirus homarus and D. Ponton (IRD, Reunion) for preliminary analyses of morphological variation in Terapon jarbua. We are grateful to three anonymous reviewers for insightful comments, helpful suggestions, and some editing. Background maps of the Indo-West Pacific were edited from images downloaded from Digital Vector Maps, San Diego (http://digitalvector-maps.com/). Fish sampling at Iles Eparses was authorized under arrêté no. 2011-32 of TAAF and was done during a cruise of RV Marion Dufresne, 01-26 April 2011. This cruise offered to four of the co-authors (PB, WJC, JDD, GMT) an opportunity to meet and socialize, and to meet DM in Reunion Island. WJC acknowledges grant support from the Ministry of Science and Technology in Taiwan (MOST 101-2611-M-002-016-MY3). The research done on Epinephelus merra and Lutjanus kasmira was funded by the European Cooperation Fund POCT-OI 2007-2013 (project CAMP). The funders had no role in the study design, data collection and analysis, decision to publish, or preparation of the manuscript.

\section{Appendix A. Database accession numbers for nucleotide sequences}

Cryobank accession number for E. fasciatus was ASIZP0800173. GenBank accession numbers for $D$. abudafur/D. aruanus were KF754733-KF754795 and 6 additional cytochrome $b$ gene sequences from Madang (GenBank nos. KT258989-KT258994); those for E. areolatus were DQ107866-DQ107870, GU324187, FJ2377 56-FJ237763, HQ149838, HQ913572, HQ945841, JN2085 69-JN208572, JX674967-JX674969, KC593374, KC970469, KF009590, KF009591, KJ130964, KJ130965, KJ202151, KJ202152, KJ607969, KM077914, KP058460 and NC_020785; those for E. fasciatus were DQ107873-DQ107876, EU392207, EU392208, EU600145, EU600146, FJ459561-FJ459563, GU805082, JQ431717, JX093907, JX674994-JX674996, KC970470, KF009593, KF489582, KF714942, KF8029400, KJ130967-KJ130969, KJ202153-KJ202155 and $\mathrm{KJ} 594972$, and an additional $\mathrm{CO} 1$ gene sequences from Glorieuses Islands (GenBank no. KT258995); those for E. merra were AY78644, JN255254-JN255345 and JN545057-JN545096; those for F. commersonii were EF607383, EF607384, JF493489, JQ349978, JQ349979, JQ431740, JQ431741, KP053133-KP053237, KP260463 and NC_010274; those for L. kasmira were JF514414-JF514500 and FJ754049-FJ754133; those for P. homarus were JN418937, JN542716, JN591360, JQ229883-JQ229888, JQ229910-JQ229926, KC959890, KC959891, KF548571, KF715528-KF715550, KF715552, and KJ802748-KJ802782; those for T. jarbua included EU871691, EU871692, FJ237549, FJ265859, HQ149959-HQ149961, JF4946 63-JF494666, JN021254, JN021255, JQ342095-JQ342111, JX260979, KC241987, KC417308, KC774674, KC970423, KF009671, KF268188, KF268189, KJ466137 and KJ466138, and 20 additional CO1 gene sequences from Iles Eparses (GenBank nos. KT231909-KT231915), Vietnam (GenBank nos KT231926-KT231928) and Taiwan (GenBank nos KT231916-KT231925). Sequences nos. EU541344, HM909801 and KJ130970 labelled "E. fasciatus" were discarded because they were found outside the E. fasciatus CO1 haplotype cluster in a preliminary Neighbour-Joining tree of serranid barcodes, hence were thought to be possibly from misidentified specimens.

\section{Appendix B. Supplementary data}

Supplementary data related to this article can be found at http:// dx.doi.org/10.1016/j.actao.2015.10.009

\section{References}

Alcantara, S.G., Yambot, A.V., 2014. DNA barcoding of commercially important grouper species (Perciformes, Serranidae) in the Philippines. Mitochondrial DNA. http://dx.doi.org/10.3109/19401736.2014.958672.

Allen, G.R., 2008. Conservation hotspots of biodiversity and endemism for IndoPacific coral reef fishes. Aquat. Conserv. Mar. Freshw. Ecosyst. 18, 541-556. 
Allen, G.R., Erdmann, M.V., 2012. Reef fishes of the East Indies. In: Tropical Reef Research, Perth, vols. I-III, p. 1292.

Arlyza, I.S., Shen, K.-N., Durand, J.-D., Borsa, P., 2013. Mitochondrial haplotypes indicate parapatric-like phylogeographic structure in blue-spotted maskray (Neotrygon kuhlii) from the Coral Triangle region. J. Hered. 104, 725-733.

Asgharian, H., Sahafi, H.H., Ardalan, A.A., Shekarriz, S., Elahi, E., 2011. Cytochrome c oxidase subunit 1 barcode data of fish of the Nayband National Park in the Persian Gulf and analysis using meta-data flag several cryptic species. Mol. Ecol. Resour. 11, 461-472.

Avise, J.C., 2000. Phylogeography: the History and Formation of Species. Harvard University Press, Cambridge MA, p. 447.

Bandelt, H.J., Forster, P., Röhl, A., 1999. Median-joining networks for inferring intraspecific phylogenies. Mol. Biol. Evol. 16, 37-48.

Beldade, R., Holbrook, S.J., Schmitt, R.J., Planes, S., Malone, D., Bernardi, G., 2012. Larger female fish contribute disproportionately more to self-replenishment Proc. Roy. Soc. B Biol. Sci. 279, 2116-2121.

Bellwood, D.R., Hughes, T.P., Connolly, S.R., Tanner, J., 2005. Environmental and geometric constraints on Indo-Pacific coral reef biodiversity. Ecol. Lett. 8, 643-651. http://dx.doi.org/10.1111/j.1461-0248.2005.00763.x.

Bellwood, D.R., Renema, W., Rosen, B.R., 2012. Biodiversity hotspots, evolution and coral reef biogeography: a review. In: Gower, D.J., Johnson, K., Richardson, J., Rosen, B.R., Ruber, L., Williams, S.T. (Eds.), Biotic Evolution and Environmental Change in Southeast Asia. Cambridge University Press, Cambridge, pp. 216-245.

Bermingham, E., Moritz, C., 1998. Comparative phylogeography: concepts and applications. Mol. Ecol. 7, 367-369.

Borsa, P., Arlyza, I.S., Chen, W.-J., Durand, J.-D., Meekan, M.G., Shen, K.-N., 2013a. Resurrection of New Caledonian maskray Neotrygon trigonoides (Myliobatoidei: Dasyatidae) from synonymy with $N$. kuhlii, based on cytochrome-oxidase I gene sequences and spotting patterns. C. R. Biol. 336, 221-232.

Borsa, P., Hsiao, D.-R., Carpenter, K.E., Chen, W.-J., 2013b. Cranial morphometrics and mitochondrial DNA sequences distinguish cryptic species of the longface emperor (Lethrinus olivaceus), an emblematic fish of the Indo-West Pacific cora reefs. C. R. Biol. 336, 505-514. http://dx.doi.org/10.1016/j.crvi.2013.09.004.

Borsa, P., Sembiring, A., Fauvelot, C., Chen, W.-J., 2014. Resurrection of Indian-Ocean humbug damselfish, Dascyllus abudafur (Forsskål) from synonymy with its Pacific-Ocean sibling, Dascyllus aruanus (L.). C. R. Biol. 337, 709-716. http:// dx.doi.org/10.1016/j.crvi.2014.09.001.

Briggs, J.C., 2003. Marine centres of origin as evolutionary engines. J. Biogeogr. 30, $1-18$.

Briggs, J.C., Bowen, B.W., 2012. A realignment of marine biogeographic provinces with particular reference to fish distributions. J. Biogeogr. 39, 12-30. http:// dx.doi.org/10.1111/j.1365-2699.2011.02613.x.

Carpenter, K.E., Barber, P.H., Crandall, E.D., Ablan-Lagman, M.C.A., Ambariyanto Mahardika, G.N., Manjaji-Matsumoto, B.M., Juinio-Meñez, M.A., Santos, M.D., Starger, C.J., Toha, A.H.A., 2011. Comparative phylogeography of the Coral Triangle and implications for marine management. J. Mar. Biol. 2011, 14.

Cracraft, J., Prum, R.O., 1988. Patterns and processes of diversification: speciation and historical congruence in some neotropical birds. Evolution 42, 603-620.

Crandall, E.D., Frey, M.A., Grosberg, R.K., Barber, P.H., 2008. Contrasting demographic history and phylogeographical patterns in two Indo-Pacific gastropods. Mol. Ecol. 17, 611-626.

Crandall, E.D., Treml, E.A., Liggins, L., Gleeson, L., Yasuda, N., Barber, P.H., Wörheide, G., Riginos, C., 2014. Return of the ghosts of dispersal past: historical spread and contemporary gene flow in the blue sea star Linckia laevigata. Bull. Mar. Sci. 90, 399-425. http://dx.doi.org/10.5343/bms.2013.1052.

DeMartini, E.E., Friedlander, A.M., 2004. Spatial patterns of endemism in shallowwater reef fish populations of the Northwestern Hawaiian Islands. Mar. Ecol. Prog. Ser. 271, 281-296.

DiBattista, J.D., Rocha, L.A., Craig, M.T., Feldheim, K.A., Bowen, B.W., 2012. Phylogeography of two closely related Indo-Pacific butterflyfishes reveals divergent evolutionary histories and discordant results from mtDNA and microsatellites. J. Hered. 103, 617-629. http://dx.doi.org/10.1093/jhered/ess056.

Drew, J., Allen, G.R., Kaufman, L., Barber, P.H., 2008. Endemism and regional color and genetic differences in five putatively cosmopolitan reef fishes. Conserv. Biol. 22, 965-975.

Durand, J.-D., Borsa, P., 2015. Mitochondrial phylogeny of grey mullets (Acanthopterygii: Mugilidae) suggests high proportion of cryptic species. C. R. Biol. 338, 266-277. http://dx.doi.org/10.1016/j.crvi.2015.01.007.

Durand, J.-D., Chen, W.-J., Shen, K.-N., Fu, C., Borsa, P., 2012. Genus-level taxonomic changes implied by the mitochondrial phylogeny of grey mullets (Teleostei: Mugilidae). C. R. Biol. 335, 687-697.

Emerson, B.C., Gillespie, R.G., 2008. Phylogenetic analysis of community assembly and structure over space and time. Trends Ecol. Evol. 23, 519-530.

Excoffier, L., Lischer, H.E.L., 2010. Arlequin suite ver 3.5: a new series of programs to perform population genetics analyses under Linux and Windows. Mol. Ecol. Resour. 10, 564-567.

Excoffier, L., Smouse, P.E., Quattro, J.M., 1992. Analysis of molecular variance inferred from metric distances among DNA haplotypes - application to human mitochondrial-DNA restriction data. Genetics 131, 479-491.

Fauvelot, C., Borsa, P., 2011. Patterns of genetic isolation in narrow-barred Spanish mackerel (Scomberomorus commerson) across the Indo-West Pacific. Biol. J. Linn. Soc. 104, 886-902.

Froese, R., Pauly, D., 2013. FishBase. World Wide Web Electronic Publication. www. fishbase.org. version (12/2013).

Gaither, M.R., Bowen, B.W., Bordenave, T.R., Rocha, L.A., Newman, S.J., Gomez, J.A., van Herwerden, L., Craig, M.T., 2011. Phylogeography of the reef fish Cephalopholis argus (Epinephelidae) indicates Pleistocene isolation across the IndoPacific barrier with contemporary overlap in the Coral Triangle. BMC Evol. Biol. $11,189$.

Gaither, M.R., Rocha, L.A., 2013. Origins of species richness in the Indo-MalayPhilippine biodiversity hotspot: evidence for the centre of overlap hypothesis. J. Biogeogr. 40, 1638-1648.

Gaither, M.R., Toonen, R.J., Robertson, D.R., Planes, S., Bowen, B.W., 2010. Genetic evaluation of marine biogeographical barriers: perspectives from two widespread Indo-Pacific snappers (Lutjanus kasmira and Lutjanus fulvus). J. Biogeogr. 37, 133-147.

Goldstein, J.S., Matsuda, H., Takenouchi, T., Butler, M.J., 2008. The complete development of larval Caribbean spiny lobster, Panulirus argus, in culture. J. Crustac. Biol. 28, 306-327.

Griekspoor, A., Groothuis, T., 2005. 4peaks: a program that helps molecular biologists to visualize and edit their DNA sequence files. http://mekentosj.com/ 4peaks/.

Hall, T.A., 1999. BioEdit: a user-friendly biological sequence alignment editor and analysis program for Windows 95/98/NT. Nucl. Acids Symp. Ser. 41, 95-98.

Hasegawa, M., Kishino, H., Yano, T., 1985. Dating of the human-ape splitting by a molecular clock of mitochondrial DNA. J. Mol. Evol. 22, 160-174. http:// dx.doi.org/10.1007/BF02101694.

He, B., Lai, T., Peng, Z., Wang, X., Pan, L., 2013. Complete mitogenome of the areolate grouper Epinephelus areolatus (Serranidae, Epinephelinae). Mitochondrial DNA 24, 498-500.

Hixon, M.A., Johnson, D.W., Sogard, S.M., 2014. BOFFFFs: on the importance of conserving old-growth age structure in fishery populations. ICES J. Mar. Sci. 71, 2171-2185. http://dx.doi.org/10.1093/icesjms/fst200.

Hoareau, T.B., Boissin, E., Paulay, G., Bruggemann, J.H., 2013. The Southwestern Indian Ocean as a potential marine evolutionary hotspot: perspectives from comparative phylogeography of reef brittle-stars. J. Biogeogr. 40, 2167-2179. http://dx.doi.org/10.1111/jbi.12155.

Hobbs, J.-P.A., Frisch, A.J., Allen, G.R., Van Herwerden, L., 2009. Marine hybrid hotspot at Indo-Pacific biogeographic border. Biol. Lett. 5, 258-261.

Hobbs, J.-P.A., Newman, S.J., Mitsopoulos, G.E.A., Travers, M.J., Skepper, C.L., Gilligan, J.J., Allen, G.R., Choat, H.J., Ayling, A.M., 2014. Checklist and new records of Christmas Island fishes: the influence of isolation, biogeography and habitat availability on species abundance and community composition. Raffles Bull. Zool. (Suppl. 30), 184-202.

Horne, J.B., van Herwerden, L., Choat, J.H., Robertson, D.R., 2008. High population connectivity across the Indo-Pacific: congruent lack of phylogeographic structure in three reef fish congeners. Mol. Phylogenet. Evol. 49, 629-638.

Hubert, N., Calcagno, V., Etienne, R.S., Mouquet, N., 2015. Metacommunity speciation models and their implication in the understanding of diversification. Ecol. Lett. 18, 864-881. http://dx.doi.org/10.1111/ele.12458.

Hubert, N., Duponchelle, F., Nuñez Rodiguez, J., Garcia Davila, C., Paugy, D., Renno, J.F., 2007. Phylogeography of the piranha genera Serrasalmus and Pygocentrus: implications for the diversification of the neotropical ichthyofauna. Mol. Ecol. 16, 2115-2136.

Hubert, N., Meyer, C.P., Bruggemann, H.J., Guérin, F., Komeno, R.J.L., Espiau, B., Causse, R., Williams, J.T., Planes, S., 2012. Cryptic diversity in Indo-Pacific coralreef fishes revealed by DNA-barcoding provides new support to the Centre-ofOverlap hypothesis. PloS One 7, e28987.

Huelsken, T., Keyse, J., Liggins, L., Penny, S., Treml, E.A., Riginos, C., 2013. A novel widespread cryptic species and phylogeographic patterns within several giant clam species (Cardiidae: Tridacna) from the Indo-Pacific Ocean. PLoS One 8, e0080858.

Hui, M., 2012. Connectivity and Evolution of Giant Clams (Tridacnidae): a Molecular Genetic Approach (PhD dissertation). Universität Bremen, Bremen. $x v \pm 85$ p.

Jackson, A.M., Tenggardjaja, K., Perez, G., Azzurro, E., Golani, D., Bernardi, G., 2015. Phylogeography of the bluespotted cornetfish, Fistularia commersonii: a predictor of bioinvasion success? Mar. Ecol. http://dx.doi.org/10.1111/maec.12249 (in press).

Jeena, N.S., 2013. Genetic Divergence in Lobsters (Crustacea: Palinuridae and Scyllaridae) from the Indian EEZ (PhD dissertation). Cochin University of Science and Technology, Kochi. xviii \pm 238 p.

Kawahara, R., Miya, M., Mabuchi, K., Lavoue, S., Inoue, J.G., Satoh, T.P., Kawaguchi, A., Nishida, M., 2008. Interrelationships of the 11 gasterosteiform families (sticklebacks, pipefishes, and their relatives): a new perspective based on whole mitogenome sequences from 75 higher teleosts. Mol. Phylogenet. Evol. 46, $224-236$.

Kimura, M., 1980. A simple method for estimating evolutionary rate of base substitutions through comparative studies of nucleotide sequences. J. Mol. Evol. 16, $111-120$.

Klanten, S.O., Choat, J.H., van Herwerden, L., 2007. Extreme genetic diversity and temporal rather than spatial partitioning in a widely distributed coral reef fish. Mar. Biol. 150, 659-670. http://dx.doi.org/10.1007/s00227-006-0372-7.

Klanten, S.O., van Herwerden, L., Choat, J.H., Blair, D., 2004. Patterns of lineage diversification in the genus Naso (Acanthuridae). Mol. Phylogenet. Evol. 32, 221-235.

Kulbicki, M., Parravicini, V., Bellwood, D.R., Arias-Gonzàlez, E., Chabanet, P., Floeter, S.R., Friedlander, A., McPherson, J., Myers, R.E., Vigliola, L., Mouillot, D. 2013a. Global biogeography of reef fishes: a hierarchical quantitative delineation of regions. PLoS One 8, e81847.

Kulbicki, M., Vigliola, L., Wantiez, L., Floeter, S., Hubert, N., Myers, R., 2013b. The 
biogeography of Chaetodontidae, a model for reef fishes ? In: Berumen, M., Pratchett, M. (Eds.), The Biology and Ecology of Butterfly-fishes. Taylor \& Francis, Boca Raton FL, pp. 70-106.

Lakra, W.S., Verma, M.S., Goswami, M., Lal, K.K., Mohindra, V., Punia, P., Gopalakrishnan, A., Singh, K.V., Ward, R.D., Hebert, P., 2011. DNA barcoding Indian marine fishes. Mol. Ecol. Resour. 11, 60-71.

Lavergne, E., Calvès, I., Meistertzheim, A.L., Charrier, G., Zajonz, U., Laroche, J., 2014. Complex genetic structure of a euryhaline marine fish in temporarily open/ closed estuaries from the wider Gulf of Aden. Mar. Biol. 161, 1113-1126. http:// dx.doi.org/10.1007/s00227-014-2404-z.

Lavery, S.D., Farhadi, A., Farahmand, H., Chan, T.-Y., Azhdehakoshpour, A., Thakur, V., Jeffs, A.G., 2014. Evolutionary divergence of geographic subspecies within the scalloped spiny lobster Panulirus homarus (Linnaeus 1758). PLoS One 9, e97247. http://dx.doi.org/10.1371/journal.pone.0097247.

Lee, J.B., Johnson, J.B., 2009. Biogeography of the livebearing fish Poecilia gillii in Costa Rica: are phylogeographical breaks congruent with fish community boundaries? Mol. Ecol. 18, 4088-4101.

Legendre, P., Legendre, L., 2012. Numerical ecology, 3rd english edn. Elsevier, Amsterdam, p. 990

Leibold, M.A., Economo, E.P., Peres-Neto, P., 2010. Metacommunity phylogenetics: separating the roles of environmental filters and historical biogeography. Ecol. Lett. 13, 1290-1299.

Leibold, M.A., Holyoak, M., Mouquet, N., Amarasekare, P., Chase, J.M., Hoopes, M.F. Holt, R.D., Shurin, J.B., Law, R., Tilman, D., Loreau, M., Gonzales, A., 2004. The metacommunity concept: a framework for multi-scale community ecology. Ecol. Lett. 7, 601-613.

Lemer, S., Aurelle, D., Vigliola, L., Durand, J.-D., Borsa, P., 2007. Cytochrome $b$ barcoding, molecular systematics, and geographic differentiation in rabbitfishes (Siganidae). C. R. Biol. 330, 86-94.

Lester, S.E., Ruttenberg, B.I., 2005. The relationship between pelagic larval duration and range size in tropical reef fishes: a synthetic analysis. Proc. Roy. Soc. Lond. Ser. B 272, 585-591.

Lester, S.E., Ruttenberg, B.I., Gaines, S.D., Kinlan, B.P., 2007. The relationship between dispersal ability and geographic range size. Ecol. Lett. 10, 745-758. http:// dx.doi.org/10.1111/j.1461-0248.2007.01070.x.

Liu, S.-Y.V., Chang, F.-T., Borsa, P., Chen, W.-J., Dai, C.-F., 2014. Phylogeography of the humbug damselfish, Dascyllus aruanus (Linnaeus, 1758): evidence of IndoPacific vicariance and genetic differentiation of peripheral populations. Biol. J. Linn. Soc. 113, 931-942. http://dx.doi.org/10.1111/bij.12378.

Luiz, O.J., Allen, A.P., Robertson, D.R., Floeter, S.R., Kulbicki, M., Vigliola, L., Becheler, R., Madin, J.S., 2013. Adult and larval traits as determinants of geographic range size among tropical reef fishes. Proc. Natl. Acad. Sci. U. S. A. 110, 16498-16502.

Mouillot, D., De Bortoli, J., Leprieur, F., Parravicini, V., Kulbicki, M., Bellwood, D.R., 2013. The challenge of delineating biogeographical regions: nestedness matters for Indo-Pacific coral reef fishes. J. Biogeogr. 40, 2228-2237. http://dx.doi.org/ $10.1111 /$ jbi.12194.

Morrone, J.J., 1994. On the identification of areas of endemism. Syst. Biol. 43. 438-441.

Morrone, J.J., Escalante, T., 2002. Parsimony analysis of endemicity (PAE) of Mexican terrestrial mammals at different area units: when size matters. J. Biogeogr. 29, 1095-1104.

Muths, D., Gouws, G., Mwale, M., Tessier, E., Bourjea, J., 2012. Genetic connectivity of the reef fish Lutjanus kasmira at the scale of the West Indian Ocean. Can. J. Fish. Aquat. Sci. 69, 842-853.

Muths, D., Tessier, E., Gouws, G., Bourjea, J., 2015. Genetic structure of the reef grouper Epinephelus merra in the West Indian Ocean appears congruent with biogeographic and oceanographic boundaries. Mar. Ecol. 36, 447-461. http:// dx.doi.org/10.1111/maec.12153.

Muths, D., Tessier, E., Gouws, G., Craig, M., Mwale, M., Mwaluma, J., Mwandya, A., Bourjea, J., 2011. Restricted dispersal of the reef fish Myripristis berndti at the scale of the SW Indian Ocean. Mar. Ecol. Prog. Ser. 443, 167-180.

Myers, A.A., Giller, P.S., 1988. Process, pattern and scale in biogeography. In: Myers, A.A., Giller, P.S. (Eds.), Analytical Biogeography. Chapman \& Hall, London, pp. 3-12.

Nelson, G.J., Platnick, N., 1981. Systematics and Biogeography: Cladistics and Vicariance. Columbia University Press, New York.

Nicolè, S., Negrisolo, E., Eccher, G., Mantovani, R., Patarnello, T., Erickson, D.L. Kress, W.J., Barcaccia, G., 2012. DNA barcoding as a reliable method for the authentication of commercial seafood products. Food Technol. Biotechnol. 50, 387-398.

Obura, D., 2012. The diversity and biogeography of western Indian Ocean reefbuilding corals. PLoS One 7, e45013. http://dx.doi.org/10.1371/ journal.pone.0045013.

Parravicini, V., Kulbicki, M., Bellwood, D.R., Friedlander, A.M., Arias-Gonzalez, J.E., Chabanet, P., Floeter, S.R., Myers, R., Vigliola, L., D'Agata, S., Mouillot, D., 2013. Global patterns and predictors of tropical reef fish species richness. Ecography 36, 1254-1262.

Pellissier, L., Leprieur, F., Parravicini, V., Cowman, P.F., Kulbicki, M., Litsios, G., Olsen, S.M., Wisz, M.S., Bellwood, D.R., Mouillot, D., 2014. Quaternary coral reef refugia preserved fish diversity. Science 344, 1016-1019.

Phillips, B.F., Matsuda, H., 2011. A global review of spiny lobster aquaculture. In: Fotedar, R., Phillips, B.F. (Eds.), Recent Advances and New Species in Aquaculture. Wiley-Blackwell, Hoboken NJ, pp. 22-84.
Rice, W.R., 1989. Analyzing tables of statistical tests. Evolution 43, 223-225.

Ricklefs, R.E., 1987. Community diversity: relative roles of local and regional processes. Science 235, 167-171.

Ricklefs, R.E., Schluter, D., 1993. Species Diversity in Ecological Communities: Historical and Geographical Perspectives. University of Chicago Press, Chicago.

Rousset, F., 1997. Genetic differentiation and estimation of gene flow from F-statistics under isolation by distance. Genetics 145, 1219-1228.

Sanciangco, J.C., Carpenter, K.E., Etnoyer, P.J., Moretzsohn, F., 2013. Habitat availability and heterogeneity and the Indo-Pacific warm pool as predictors of marine species richness in the tropical Indo-Pacific. PLoS One 8, e56245. http:/ dx.doi.org/10.1371/journal.pone.0056245.

Santini, F., Winterbottom, R., 2002. Historical biogeography of Indo-western Pacific coral reef biota: is the Indonesian region a centre of origin? J. Biogeogr. 29, 189-205.

Scheltema, R.S., 1968. Dispersal of larvae by equatorial currents and its importance to the zoogeography of shoal-water tropical species. Nature 217, 1159-1162.

Schoelinck, C., Hinsinger, D.D., Dettaï, A., Cruaud, C., Justine, J.-L., 2014 A phylogenetic re-analysis of groupers with applications for ciguatera fish poisoning. PLoS One 9, e98198. http://dx.doi.org/10.1371/journal.pone.0098198.

Selkoe, K.A., Toonen, R.J., 2011. Marine connectivity: a new look at pelagic larval duration and genetic metrics of dispersal. Mar. Ecol. Prog. Ser. 436, 291-305. http://dx.doi.org/10.3354/meps09238.

Senevirathna, J., Munasinghe, D., Jan. 28-29, 2014. Genetic diversity and population structure of Panulirus homarus populations of Southern Sri Lanka and South India revealed by the mitochondrial COI gene region. Proc. Int. Conf. Food, Biol. Med. Sci. 10-13. Bangkok.

Sims, C.A., Riginos, C., Blomberg, S.P., Huelsken, T., Drew, J., Grutter, A.S., 2014 Cleaning up the biogeography of Labroides dimidiatus using phylogenetics and morphometrics. Coral Reefs 33, 223-233. http://dx.doi.org/10.1007/s00338013-1093-2.

Slatkin, M., 1985. Gene flow in natural populations. Annu. Rev. Ecol. Syst. 16, $393-430$

Smith, M.M., Heemstra, P.C. (Eds.), 1986. Smith's Sea Fishes. Macmillan Publ. Co., Johannesburg, p. 1047, 144 pls.

Spalding, M.D., Fox, H.E., Allen, G.R., Davidson, N., Ferdana, Z.A., Finlayson, M., Halpern, B.S., Jorge, M.A., Lombana, A., Lourie, S.A., Martin, K.D., McManus, E., Molnar, J., Recchia, C.A., Robertson, J., 2007. Marine ecoregions of the world: a bioregionalization of coastal and shelf areas. BioScience 57, 573-583.

Tamura, K., 1992. Estimation of the number of nucleotide substitutions when there are strong transition-transversion and $\mathrm{G}+\mathrm{C}$ content biases. Mol. Biol. Evol. $678-687$.

Tamura, K., Nei, M., 1993. Estimation of the number of nucleotide substitutions in the control region of mitochondrial DNA in humans and chimpanzees. Mol. Biol. Evol. 19, 512-526.

Tamura, K., Stecher, G., Peterson, D., Filipski, A., Kumar, S., 2013. MEGA6: molecular evolutionary genetics analysis version 6.0. Mol. Biol. Evol. 30, 2725-2729.

Treml, E.A., Roberts, J.J., Chao, Y., Halpin, P.N., Possingham, H.P., Riginos, C., 2012. Reproductive output and duration of the pelagic larval stage determine seascape-wide connectivity of marine populations. Integr. Comp. Biol. 52, 525-537. http://dx.doi.org/10.1093/icb/ics101.

Veron, J., Stafford-Smith, M., DeVantier, L., Turak, E., 2015. Overview of distribution patterns of zooxanthellate Scleractinia. Front. Mar. Sci. 1, 81.

Vogler, C., Benzie, J., Barber, P.H., Erdmann, M.V., Ambariyanto, Sheppard, C., Tenggardjaja, K., Gerard, K., Woerheide, G., 2012. Phylogeography of the Crownof-Thorns starfish in the Indian Ocean. PLoS One 7, e43499.

Ward, R.D., Zemlak, T.S., Innes, B.H., Last, P.R., Hebert, P.D.N., 2005. DNA barcoding Australia's fish species. Philos. Trans. R. Soc. B 360, 1847-1857.

Whitney, N.M., Robbins, W.D., Schultz, J.K., Bowen, B.W., Holland, K.N., 2012 Oceanic dispersal in a sedentary reef shark (Triaenodon obesus): genetic evidence for extensive connectivity without a pelagic larval stage. J. Biogeogr. 39, 1144-1156.

Winters, K.L., van Herwerden, L., Choat, J.H., Robertson, D.R., 2010. Phylogeography of the Indo-Pacific parrotfish Scarus psittacus: isolation generates distinctive peripheral populations in two oceans. Mar. Biol. 157, 1679-1691. http:// dx.doi.org/10.1007/s00227-010-1442-4.

Woodland, D.J., 1990. Revision of the fish family Siganidae with description of two new species and comments on distribution and biology. Indo Pac. Fishes B. Pauahi Bish. Mus. Honol. 19, 1-136.

Wörheide, G., Epp, L.S., Macis, L., 2008. Deep genetic divergences among IndoPacific populations of the coral reef sponge Leucetta chagosensis (Leucettidae): founder effects, vicariance, or both? BMC Evol. Biol. 8, 24. http://dx.doi.org/ $10.1186 / 1471-2148-8-24$.

Wright, S., 1942. Isolation by distance. Genetics 28, 114-138.

Zemlak, T.S., Ward, R.D., Connell, A.D., Holmes, B.H., Hebert, P.D.N., 2009. DNA barcoding reveals overlooked marine fishes. Mol. Ecol. Resour. 9 (Suppl. 1) 237-242. http://dx.doi.org/10.1111/j.1755-0998.2009.02649.x.

Zhang, J., 2011. Species identification of marine fishes in China with DNA barcoding. Evid. Based Complement. Altern. Med. 2011, 978253. http://dx.doi.org/10.1155/ 2011/978253.

Zhuang, X., Qu, M., Zhang, X., Ding, S., 2013. A comprehensive description and evolutionary analysis of 22 grouper (Perciformes, Epinephelidae) mitochondrial genomes with emphasis on two novel genome organizations. PLoS One 8 e73561. 